Historic, archived document

Do not assume content reflects current scientific knowledge, policies, or practices. 



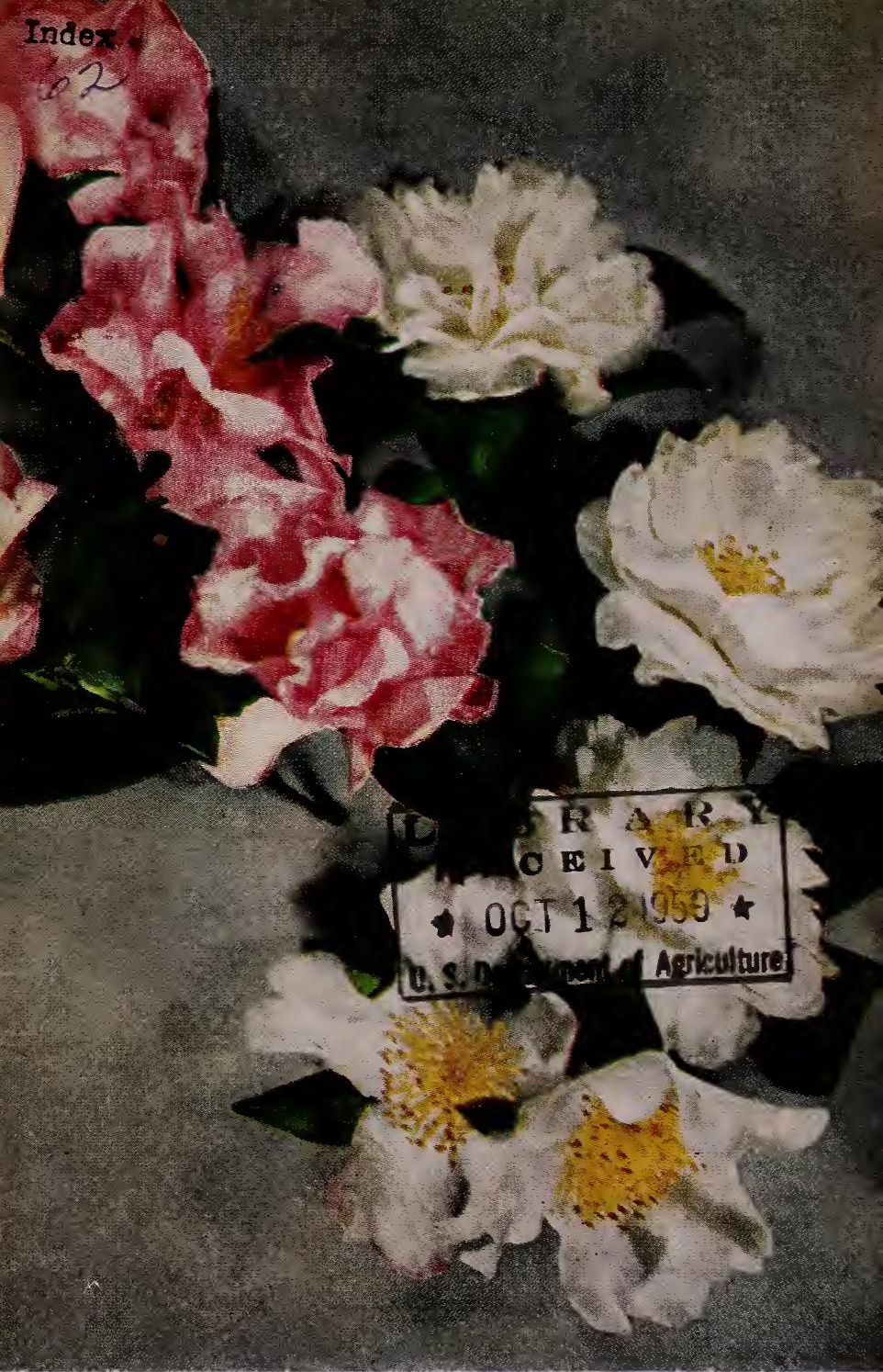

\section{Camellia Sasanqua}

\section{FROTLAND U. Murseries}

ESTABLISHED IN 1856

2505 WASHINGTON RD. AUGUSTA, GA. PHONE RE 3-7927 PHONE RE 3-8033

SEASON $1958-1959$ 


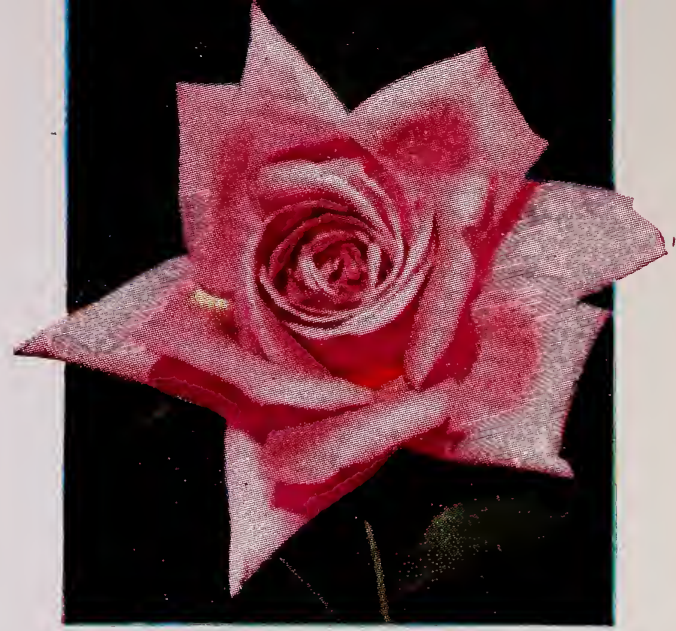

EDITOR MCFARLAND

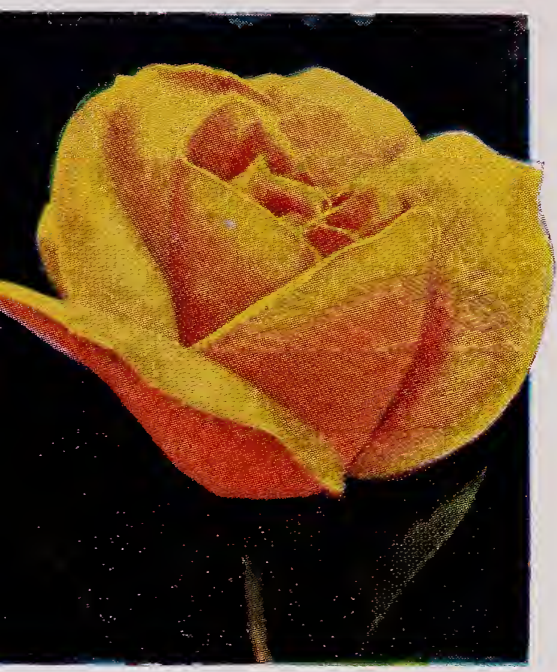

2-Year

\section{Field}

Grown

Roses

LUXEMBOURG

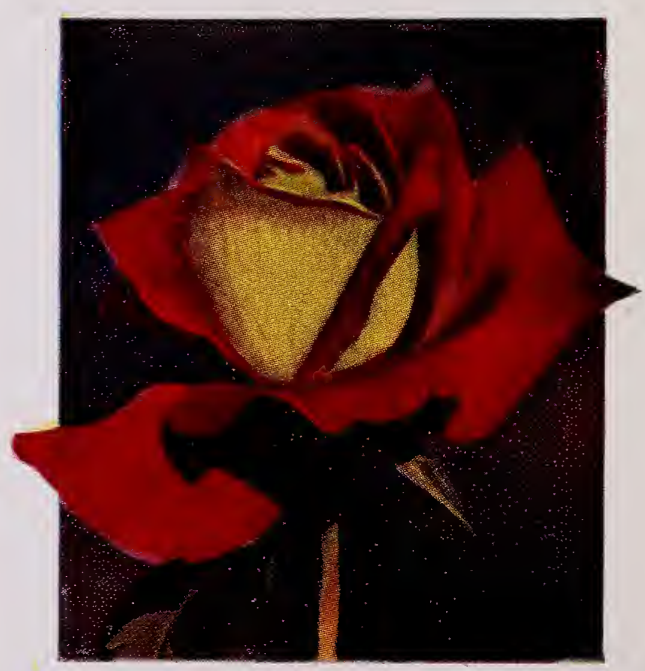

CONDESA DE SASTAGO 
We hope you will like the layout of our new catalog. You will notice that all the items have been put in alphabetical order from $\mathrm{A}$ to $\mathrm{Z}$, thus enabling you to find them more easily.

The Nurseries are located at 2505 Washington Road on U. S. Highway \#28 west of Augusta. Phones Regent 3-8033 and 3-7927. We would like for you to visit us at our new modern Garden Center where you will find all your needs for a fine garden. WE ARE NOT OPEN FOR BUSINESS ON SUNDAY.

Our Nurseries are inspected annually by our State Plant Board and we guarantee our trees and plants to be in a healthy condition, true to name, up to grade and first class in every respect when leaving our hands. WE HAVE NO AGENTS. When requesting information or advice, please enclose stamped envelope.

WHEN TO PLANT. Our shipping season opens in the Fall after good rains and frost, and continue through April. We have many plants in containers that can be shipped at any time.

Any complaints or errors must be reported within sixty days. We cannot be responsible for plants dying from lack of water or other things beyond our control.
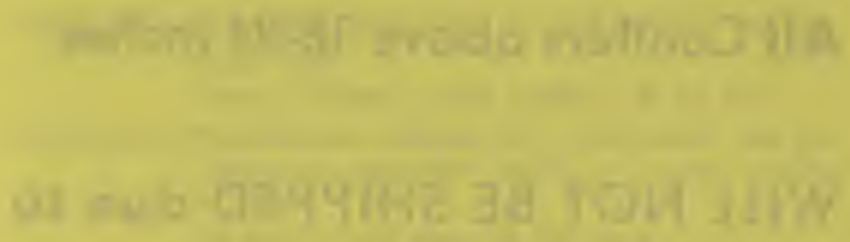

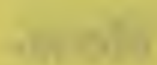

\section{TERMS}

Cash with order unless credit prearranged. If C.O.D. shipment is preferred, order must be accompanied with a deposit of 50 per cent. All prices F.O.B. Augusta. NO ORDER WILL BE ACCEPTED FOR LESS THAN $\$ 3.00$ DUE TO INCREASE IN SHIPPING COST. 


\section{PLEASE NOTE}

Due to problems and costs involved we hereby state:

All fruit trees above 4-5 feet

All flowering shrubs above 3-4 feet

All Broadleaved Evergreens above 18-24 inches

All Conifers above 18-24 inches

WILL NOT BE SHIPPED due to high transportation costs. However we do invite you to visit our nursery prepared to take your plants with you regardless of size and quantity. 


\section{RETAIL LIST 1958-59}

Abelia Edward Goucher. New, dwarf, with deep pink flowers. Handsome foliage. Evergreen.

$18-24$ in. @ $\$ 1.00 ; 3$ or more @ \$.90 each 2-3 ft.@1.98; 3 or more@1.80 each

Abelia Grandiflora. Very hardy evergreen having light pink flowers; glossy foliage. Medium height. $12-18$ in. @ \$.50; 3 or more@\$.40 each 18-24 in.@1.00; 3 or more@ .80 each 2-3 ft. @1.49; 3 or more@1.35 each 3-4 ft. @1.79;3 or more@1.65 each

Acer Rubrum. Fast growing maple. Makes a good shade tree. Colorful. Very desirable.

$3-4$ ft.@\$2.50

4-5 ft.@3.00

5-6 ft.@4.00

6-8 ft.@6.00

8-10 ft.@8.00

Agave Americana. Century plant. Unusual. Nice for urns. Very hardy evergreen. Exotic.

Cans@\$1.00

Ajuga Repens. Very nice ground cover. Dark green foliag'e. Intense blue flower. Does well in shady locations.

(a) 20c;3 or more@18c each

Albizzia Julibrissin. (Mimosa). Deciduous ornamental tree. Beautiful, soft pink powder-puff-like flowers in summer. Spreading habit. Fast grower.

$3-4$ ft. @ $\$ 2.00$

4-5 ft.@2.49

5-6 ft.@2.79

Alternanthera. Annual border plant used strictly for foliage color.

Green foliage - Red foliage; $\$ 1.25 \mathrm{doz}$.

Ampelopsis Tricuspidata (Boston Ivy). Deciduous vine for concealing unsightly walls, etc. Very colorful in fall.

@ $\$ 1.00 ; 3$ or more@90c each

Amygdalus (Flowering Peach).

Rubra. Large, double red flowers in profusion. Very conspicuous.

White. Large, double white flowers in spring. Fresh as new fallen snow.

Variegated. The peppermint look. Color of flowers vary from pure white to pink and white to solid red. Most unusual.

$3-4$ ft. @ \$1.59; 3 or more @\$1.49 each 4-5 ft. @2.00; 3 or more@1.90 each

Antigonon (Coral Vine).

Perennial vine, producing dainty pink flowers in clusters in late summer. Excellent for trellis and arbor work.

Tubers@75c 


\section{Antigonon}

White. Same as above, except flowers are white.

@ $\$ 2.00$

Apples. Fruiting varieties.

$\rightarrow$ Delicious. Large, red, ripens in fall. 4-6 ft.@\$1.69 each; 3 or more @\$1.59 each Early Harvest. Yellow, well flavored. Summer. 4-6 ft. @\$1.69 each; 3 or more@\$1.59 each

- Grimes Golden. Greenish-yellow; sub-acid. Fall.

4-6 ft. @\$1.69 each; 3 or more @ \$1.59 each

- Lodi. Very large yellow; good flavor and texture. Recommended. June.

4-6 ft. @\$1.69 each; 3 or more@\$1.59 each

$\rightarrow$ Red June. Medium-sized, deep red. Juicy. June.

4-6 ft. @\$1.69 each; 3 or more@\$1.59 each

- Stayman Winesap. Dark red. Brisk; crisp. Winter.

4-6 ft. @\$1.69 each; 3 or more@\$1.59 each

$>$ Winter Queen. Large yellow-green; sub-acid. October.

4-6 ft.@\$1.69 each; 3 or more@ @1.59 each

Crabapple - Transcendent. Yellow, stippled-red. Good.

4-6 ft. @\$1.69 each; 3 or more @\$1.59 each

Aquilegia. Columbine. Long-spurred hybrids. Good in perennial borders.

Blue and white combination

Crimson and blue combination

White

Yellow

$40 \mathrm{c}$ each

Arundo Donax. Giant reed; cane-like plant. Perennial grass. Foliage green. Tropical appearance.

@59c;3 or more@49c each

Arundo Donax Variegated. Same as above only foliage is green striped white. Very decorative.

@59c;3 or more@49c each

Aspidistra Lurida. Low evergreen stemless plant. Very large leaves. Excellent material for floral arrangements. Likes deep shade. Good ground cover.

@ 25c per leaf

Aucuba Japonica. Large green leaved plant. Evergreen. Does well in shady locations. Medium height. Female produces red berries.

8-12 in.@\$1.49; 3 or more@ @1.39 each 12-15 in.@1.79; 3 or more@1.69 each 15-18 in.@1.85; 3 or more@1.75 each 18-24 in.@3.00;3 or more@2.90 each

Aucuba Japonica Variegata. Conspicuous gold-dust plant. An arranger's dream. Foliage flecked with bright yellow markings. For shady locations. 
AZALEAS (Glenn Dale, Kurume, Pericat).

Apple Blossom (Kurume). Very delicatetwo shades of salmon pink. Hardy; early; moderate height.

6-8 in., 8-10 in., 12-15 in., 15-18 in., 18-24 in.

Autumn Sunset (Pericat). A hybrid of our own introduction. Deep brick-red flower. Late. Most attractive. Hardy. 6-8 in. to $18-24$ in.

Bridesmaid (Kurume). Deep salmon-pink. Attractive. Medium height. 6-8 in. to 18-24 in.

Buccaneer (Glenn Dale). New introduction. Late bloomer. Deep reddish-salmon flower. Bushy compact grower. Hardy. 6-8 in. to 15-18 in.

Christmas Cheer (Kurume). Double dark Christmas-red. Very hardy and popular. Upright grower. $6-8$ in. to $12-15$ in.

Coral Bells (Kurume). Favorite double pink. Hardy; showy; tall grower. 6-8 in. to 15-18 in.

Daybreak (Kurume). Very hardy light madder pink. Early. Bright as the morning sunrise. $12-15$ in. to $18-24$ in.

Fashion (Glenn Dale). Very attractive foliage. Compact grower. Deep double salmon-pink flowers. One of newer ones. 6-8 in. to 18-24 in.

Flame (Kurume). Deep brick red; single flower. Early. Very hardy. Upright. 8-10 in.

Glamour (Glenn Dale). Late bloomer. Large deep rose flower. Good habit of growth. New. 6-8 in. to $2-3 \mathrm{ft}$.

Hexe (Kurume). Very dwarf; deep double red. Very conspicuous and hardy. Late. 10-12 in.

H. H. Hume. Brand new. Superb double white. Moderate height. First time offered at popular prices. A must for those who care. $6-8$ in. to $18-24$ in.

Hinodegiri (Kurume). Dwarf, crimson-red. Very compact and conspicuous in landscape. 6-8 in. to $12-15$ in.

Hinomayo (Kurume). Light pink. Very striking. Profuse bloomer. Hardy. Tall grower. 10-12 in. to $2-3 \mathrm{ft}$.

Mountain Laurel (Kurume). Delicate light salmon pink flowers in profusion. Early; hardy. Moderate height. 10-12 in., 18-24 in.

Pink Jewel (Kurume). Low grower. Bushy; compact. Exquisite clear pink flowers in profusion. 6-8 in., 8-10 in., 12-15 in., 15-18 in., 18-24 in.

Polar Bear (U.S.D.A.) Just recently introduced. Large, double white. Improvement on Snow. $6-8$ in. to $24-30$ in.

Salmon Queen (Kurume). Beautiful, soft, salmon pink flowers. Low; compact grower.

6-8 in., 8-10 in., 12-15 in., $15-18$ in., 18-24 in.

Snow (Kurume). Double white; very hardy and popular. Medium height. 6-8 in. to 18-24 in. 
Snowhite (U.S.D.A.) Another new introduction. In same class as Polar Bear. For those who want the best. 8-10 in. to 24-30 in.

Star Dust (Glenn Dale). Early, tall grower; white flowers in profusion. Very hardy. 8-10 in. to $12-15$ in.

Sweet Briar (Kurume). Beautiful double pink. Upright grower. Hardy. 10-12 in.

Treasure (Glenn Dale). The best large flowering white Azalea. Unusual. Hardy; tall; bushy. 8-10 in. to $12-15$ in.

Trouper (Kurume). New introduction. Flowers, red, foliage compact, glossy, brand new. 6-8 in., 8-10 in.

\section{PRICES - Glenn Dale, Kurume, Pericat:}

6-8 in.@\$.85 each; 3 or more @ \$.75 each 8-10 in.@1.00 each;3 or more@.90 each 10-12 in.@1.49 each; 3 or more@1.39 each 12-15 in.@1.89 each;3 or more@1.79 each 15-18 in.@2.49 each;3 or more@2.39 each 18-24 in.@3.49 each;3 or more@3.39 each 24-30 in.@4.49 each;3 or more@4.39 each 30-36 i11.@5.00 each; 3 or more@4.90 each

AZALEAS (Indica and Kaempferi).

Brilliant. Hardy, deep rose-red flower. Best red for Augusta vicinity. Late.

15-18 in., 18-24 in.

Formosa. Handsome evergreen. Large magenta colored flowers in profusion. Excellent foundation material. 10-12 in. to 18-24 in.

George Taber. Large, mauve flower. Attractive foliage. $12-15$ in.

Iveryana. Bushy, compact growth. Very hardy. Large, variegated pink and white flowers. Late. 15-18 in.

Judge Solomon. A sport of Formosa. Same appearance of foliage, but with pink flowers. 10-12 in. to $15-18$ in.

Lawsal. Tall grower. Very hardy. Beautiful light salmon blossoms. Most reliable. 10-12 in.

Kaempferi. Late, clear pink flower. Tall. Extremely hardy. Excellent for massing. 10-12 in.

Kaempferi Lilac. Unusual light lavender flower with stamen and pistil white. Good habit of growth. Bushy. A hybrid introduced by FRUITLAND! 8-12 in.

President Clayes. Tall grower. Very hardy and reliable. Flowers deep reddish-salmon. Conspicuous. 10-12 in.

Vittata Fortunei. Variegated magenta and white flower. Very early and hardy. The first harbinger of spring. 8-12 in.

\section{PRICES INDICA and KAEMPFERI}

10-12 in.@\$.69 each; 3 or more @ \$.59 each 12-15 in.@1.00 each; 3 or more@.90 each 15-18 in. @1.49 each; 3 or more @1.39 each 18-24 in. @2.29 each; 3 or more@2.09 each 
Bambusa Multiplex (variety). Compact clump type. Excel-

lent for screening. Absolutely will not spread and become a pest. Beautiful texture reeds. Little care. Maximum height 10-12 ft.

Strong divisions

$\$ 1.00$ each; 3 or more @ \$.90 each Etxra strong divisions

$\$ 1.49$ each; 3 or more @ \$1.39 each

Begonia. Rex. Variegated foliage. Excellent pot plant.

$50 \mathrm{c}$ each

Beleperone Guttata. Shrimp plant. Unusual pot plant. Flower resembles color and form of shrimp. Different.

4 in. Pot@25c each

Berberis Julianae. Very attractive evergreen. Graceful. Yellow flowers in spring. Stands abuse. Medium height.

$10-12$ in. from beds, $50 \mathrm{c}$ each:

3 or more@\$.40 each 15-18 in.@\$2.29 each; 3 or more@2.20 each 18-24 in. @2.79 each; 3 or more@2.69 each 24-30 in. @3.00 each;3 or more@2.90 each 30-36 in. @ 4.00 each; 3 or more @ 3.85 each

Bignonia Capreolata. Evergreen trumpet vine. Excellent for trellis and arbor. Hardy, attractive.

(c) $\$ 1.00$

Bignonia Chamberlayni. New. Yellow, purple throat marking's.

(a) $\$ 1.00$

Bignonia Venusta (Flame Vine). Light orange-yellow flower in profusion. Greenhouse plant. 4-inch pots $75 \mathrm{c}$ each.

\section{BULBS}

Amaryllis. White.

Foliage dark green. Flower large, white, lily form. Strong bulbs. $\$ 1.25$ each.

Anemone. Beautiful; decorative. Flowers in spring. Good for cutting. Blue, pink, red, white. .75 doz.

Daffodil (Narcissi).

King Alfred. Large yellow. Very popular. Strong bulbs. $\$ 1.00$ doz.

Jumbo Size. $\$ 1.50$ doz.

Mount Hood. Pure white; creamy white trumpet. Beautiful. Strong bulbs. $\$ 1.50$ doz. Selma Lagerlof. Large, pure white perianth; Red crown, edged yellow. $\$ 1.50 \mathrm{doz}$.

Dutch-Iris. Excellent cut flowers in spring. Hardy. Thrifty. Plant in fall.

Blue

Bronze

Mauve

White

Yellow

50 c per doz. 
Hyacinths.

City of Haarlem. Pale yellow. Large spike.

King of Blues. Dark blue; well formed.

L'Innocence. Pure white; large bells; fine spike. None better.

LaVictoire. Brilliant carmine red.

Perle Brilliant. Good light blue.

Queen of the Pink. Beautiful pink.

Price, above Hyacinths. $\$ 1.25$ doz.

Hyacinths.

Grape Hyacinths in blue or white. Attractive spring flowers - ideal for ground cover.

Price of Grape Hyacinths. .60 doz.

Lycoris. Spider Lily.

Aurea. Yellow flowers in summer. 50c each Radiata. Red cluster on long stems before foliage appears in late summer. $79 \mathrm{c}$ doz.

Snowdrops. Always found in older gardens. White blooms, resembling Lily-of-the-valley.

Bulbs. $\$ 1.75$ doz.

Tulips.

Clara Butt. Well known pink. 79c per doz.

Eros. Double pink. If you have not tried this you have missed something. 79c per doz.

Firebrand. Red. $79 \mathrm{c}$ per doz.

Golden Age. Yellow. Good. 79c per doz.

It. Tacoma. Double white. Very pretty.

$79 \mathrm{c}$ per doz.

Maureen. Very large, new white.

$\$ 3.00$ per doz.

Niphetos. Light yellow. 79c per doz.

Red Emperor. Extra fine red. Recommended.

$79 \mathrm{c}$ per doz.

Roosevelt. Very large red. $\$ 1.50$ per doz.

Scarlet O'Hara. Brilliant red. $\$ 1.85$ per doz.

Spring Song. Scarlet sensation. $79 \mathrm{c}$ per doz.

Sunshine. Bright yellow. $79 \mathrm{c}$ per doz.

Swanenburg. Nice white. $79 \mathrm{c}$ per doz.

Symphonia. Double deep pink. Very attractive. $79 \mathrm{c}$ per doz.

Zephyranthes. Fairy or Rain Lily.

Atamasco. White. Very beautiful planted in drifts.

Rosea. Rose-pink form of above. Rare.

Price above two: $\$ 1.50$ per doz.

Buxus Harlandi (Boxwood). Dwarf; dark green, handsome foliage. Slow growing. Good edging for walks, etc.

6-8 in.@\$.75 each; 3 or more @ \$.65 each

8-10 in.@1.20 each;3 or more@1.10 each

10-12 in.@1.49 each;3 or more@1.39 each

12-15 in.@2.50 each;3 or more@2.25 each 
Buxus Japonica. The hardiest Boxwood for our climate. Good grower; few pests; stands heat. Recommended.

4-6 in.@\$.45 each;3 or more@ \$.40 each 6-8 in.@.65 each; 3 or more @.60 each 8-10 in.@.85 each;3 or more@.75 each 10-12 in.@1.50 each;3 or more@1.35 each 12-15 in.@2.59 each;3 or more@2.45 each 15-18 in.@2.89 each;3 or more@2.75 each 18-24 in.@3.50 each;3 or more@3.25 each

Calycanthus Floridus (Sweet Shrub). Native deciduous shrub having deep reddish-purple flowers. Sweet scented. Medium height. Excellent massing material.

18-24 in.@\$1.49 each; 3 or more@\$1.39 each 2-3 ft.@1.59 each;3 or more@1.49 each

\section{CAMELLIA JAPONICA}

Alba Plena. A most beautiful, full, double white; early, but rather tender. Excellent. 15-18 in., 18-24 in.

Berenice Boddy. Very hardy; semi-double white edged pink. Most reliable and beautiful. Upright grower. 12-15 in., 15-18 in.

C. M. Hovey, Large, double dark red; full double; late bloomer. A good choice. 12-15 in., 24-30 in., 30-36 in.

Cup of Beauty. Semi-double pink. When bud begins to unfold it holds tight bud in center, resembling cup and saucer. Compact grower. 24-30 in., $30-36$ in.

Daybreak. Semi-double, light pink. Good flower. 8-12 in.

Debutante. Just iïs a young. beautiful girl. Soft, radiant pink. Semi-double. Early. Upright grower. 18-24 in. to $30-36$ in.

Doctor Lee. Semi-double, dark red. Attractive; rugged; hardy. 15-18 in.

E. H. Folk. Extra large, semi-double, deepest red. Very showy. Hardy. Late. 18-24 in.

Elegans. Another of the old timers - still in a class of it's own. Large, semi-double, soft pink blotched white. Magnificent.

8-12 in., $12-15$ in., $18-24$ in. $24-30$ in.

Elena Nobile. Good, double, dark red. 18-24 in., 24-30 in.

Enrico Bettoni. Semi-double, salmon-pink. Good bloomer. Mid-season; tall. 12-15 in., 15-18 in.

Finlandia (White Herme). Semi-double white. Mid-season; hardy. $8-12$ in. $18-24$ in. to $30-36$ in.

Frizzle White. Very large semi-double pure white with yellow stamens. Ruffled; very beautiful. Midseason. 18-24 in.

Gigantea. Very large, bold red with white markings. Dark, handsome large foliage. Spreading nature. 15-18 in., 24-30 in., 30-36 in.

Gov. Earl Warren. Large semi-double pink. Very beautiful! Late. 18-24 in.

Gov. Mouton. Semi-double, dark red mottled white. Bushy; Mid-season. Excellent! 15-18 in. 
H. A. Downing (MS-L). Large, semi-double, deep rose. Prominent stamens. Hardy. 8-12 in., 12-15 in.

Herme. Semi-double pink - petals edged white. Fragrant. Upright grower. Mid-season. Hardy. 8-12 in. to $3-4 \mathrm{ft}$.

Herme Pink. Solid pink, semi-double. Upright. Not common. 24-30 in., 30-36 in.

Herme Sport. Semi-double white, flecked pink. Hardy. 8-12 in., $12-15$ in., $24-30$ in.

Imperator (L). Christmas-red peony type. Beautiful. 8-12 in., 12-15 in.

Jenny Jones. Large, pure white from West Coast. Very good. Semi-double. 12-15 in., 15-18 in.

Joe Holland (MS). Large, deep pink; semi-double. Desirable. 18-24 in., 24-30 in., 30-36 in.

Kumasaka. Nice semi-double pink. Very hardy and reliable. Late. Upright grower. 8-12 in. to 24-30 in.

Kumasaka Variegated. Variegated version of the Kumasaka. 8-12 in., 18-24 in., 24-30 in.

Lady Clare (MS). Very large, deep pink with stamens. Handsome foliage. A must for your garden. 12-15 in., $15-18$ in., $18-24$ in., $24-30$ in., 30-36 in., 3-4 ft.

Lady Clare Variegated. Same as above, except with distinctive and unusual white markings. Most desirable.

8-12 in., $15-18$ in., $18-24$ in., $24-30$ in., $30-36$ in., 3-4 ft.

Lady Mary Cromartie Pink. Large, semi-double, deep pink. Mid-season. Very showy. 10-12 in.

Lady Vansittart (MS). Semi-double, cherry-red with yellow stamens. Large flower. Compact grower.

10-12 in.

Lallarook (MS). Large, double, soft pink, marked white. Good greenhouse variety. 15-18 in.

Latifolia (L). Red, sometimes blotched white. Unusually handsome foliage. Good reliable grower. 8-12 in. to $30-36$ in.

Marchioness of Exeter (MS). Good semi-double pink and white variegated. Color variable.

15-18 in., 18-24 in.

Margaret Higdon (MS). Large, rose-red. Not common. Vigorous grower. 18-24 in.

Mathotiana (MS-L). Very large, imbricated crimson with purple cast. $8-12$ in. to $3-4 \mathrm{ft}$.

Mathotiana Rosea. Same as above except flowers rose colored. 10-12 in., 12-15 in.

Mathotiana Var. A variegated type of above. Worthwhile. 8-12 in. to $15-18$ in. 
Mollie Moore Davis. Deep rose-pink sport of Big Beauty. 10-12 in.

Monarch. Large, peonyform, deep pink. Good grower; handsome foliage. Late. $12-15$ in. to $24-30 \mathrm{in}$.

Nagasaki (MS). Beautiful, soft pink, marked white. Slow, spreading growth. Not common. 12-15 in. Always good. 10-12 in., 15-18 in., 18-24 in.

Rer. John Bennett Var. Variegated form of above. Very desirable. 10-12 in., 15-18 in., 18-24 in.

Rev. John G. Drayton (E-MS). Semi-double, light pink with stamens. Vigorous, compact, upright growth. 24-30 in., 30-36 in.

Rosary FN (MS-L). One of our best introductions. Most distinctive fluted petals. Soft, semi-double pink. Highly recommended. 8-12 in. to 18-24 in.

Rosea Plena. Nice, double pink. Petals veined deep rose. 10-12 in. to $18-24$ in.

Sarasa Pink. Salmon pink sport of Sarasa. 15-18 in.

Semi-Double Blush. Soft, light pink. Desirable and hardy. Bushy. 4-5 ft., 5-6 ft.

Stiles Perfection. Very light, semi-double pink and white. One of the older varieties. Tall, upright grower. 15-18 in., 18-24 in.

Swan. Pure white - semi-double. Good. 24-30 in., 30-36 in.

TeDeum. Striking, large, dark red, fireball. Late. 12-15 in., 24-30 in.

Tricolor (IIS-L). Medium-size, rugged grower. Semi-double, medium-size variable flowers - solid red to white. $24-30$ in.

Otome (MS). Medium-size, double, soft pink. Attractive. 15-18 in., 18-24 in.

Palmer Gillette (MS). Large white, peony-form, worthy. Very well known on West Coast. 15-18 in.

Pink Perfection. Double, soft pink. Formal. Prolific. Always dependable. Very popular. $15-18$ in. to $30-36$ in.

Pink Star (MS-L). Large. semi-double pink, veined deepest rose-pink. Very beautiful. $15-18$ in. to 18-24 in.

Pope Pius. Double red. Medium-size flower. Prolific. Good variety. 8-12 in., 12-15 in., 15-18 in., 18-24 in., 24-30 in., 30-36 in.

Prof. Sargent. Well known, early, deep red pompon type. Very rugged and showy. 12-15 in., 15-18 in., 24-30 in. to 3-4 $\mathrm{ft}$.

Purity. Medium-sized, double white. Mid-season. Fluted petals. One of the best double whites. 8-12 in., 18-24 in. 
Rainy Sun (L). Very large, semi-double crimson-red. Prominent stamens. Good. 12-15 in., 15-18 in., 3-4 ft., 4-5 ft.

Red Eagle (M). Light red, semi-double. Vigorous grower. 12-15 in.; $15-18$ in.

Rev. John Bennett. Large, semi-double, salmon-pink with white markings in throat. Prominent stamens.

White Giant (MS-L). Very large, semi-double, pure white. Noble. 12-15 in.

Williams Lavender. Unusually good bloomer. Single, lavender-pink flowers which last a long time. Makes good colorful hedge for early winter bloom. 12-15 in., 15-18 in., 18-24 in., 2-3 ft.

Yours Truly (MS-L). Most striking color combination of pink and white. Unusual. Highly recommended. $8-12$ in. to $15-18$ in.

\section{PRICES ABOVE VARIETIES:}

8-12 in.@\$.85 ea.; 3 or more@\$.75 ea. 12-15 in.@1.15 ea.; 3 or more@1.00 ea. 15-18 in.@1.59 ea.; 3 or more@1.40 ea. 18-24 in.@2.29 ea.; 3 or more@2.10 ea. 24-30 in.@3.25 ea.; 3 or more@3.00 ea. 30-36 in.@4.25 ea.; 3 or more@4.00 ea. 3-4 ft.@4.75 ea.; 3 or more@4.25 ea. 4-5 ft.@10.00 ea.; 3 or more@9.50 ea.

\section{CAMELLIA JAPONICAS - UNUSUAL}

Daikagura (E). Large, bright rose-pink, splotched white. Begins blooming in October. Slow grower.

Donckelarii (MS). Large, semi-double, red blotched white. Always a favorite.

Ville de Nantes (MS-L). Large, dark red, blotched white. Fimbriated petals. None better.

\section{PRICES ABOVE THREE:}

8-12 in. $\$ 2.59$ each

12-15 in. 3.00 each

$15-18$ in. 3.85 each

18-24 in. 5.00 each

\section{CAMELLIA SASANQUAS.}

Blush. Very soft pink; single flower. Compact grower. Excellent screen plant. 12-15 in. to 30-36 in.

Cherry Blossom. Large, single flowers, white edged pink. Dainty. Upright grower. 15-18 in., 18-24 in.

Cleopatra. Semi-double pink. Extremely popular. Very dark green foliage. Compact grower. 12-15 in. to $30-36$ in.

Dauphine. New! Single, deep pink. Dense, upright grower. Good for hedge or formal planting. 8-12 in. 
Dawn. Tall, open grower. Very hardy. Semidouble white, tinged soft pink. Withstands low temperatures. $12-15$ in.

Hinode-gumo. Large, beautiful, frilly white, tinged pink on edges of petals. Striking. 18-24 in. to $30-36$ in.

Mine-no-yuki. Large, double, pure white; drooping habit; adaptable to espalier work. Resembles a snow bank when in flower. 12-15 in. to $30-36$ in.

North Star. Tall, upright, bushy growth. Flowers 5 pointed white, tipped pink. Vigorous. $15-18$ in. to $30-36$ in.

Oleifera. Large white flower - rimmed pink. Good grower. $12-15$ in., $15-18$ in., 18-24 in., 24-30 in.

Orchid FN. A Fruitland introduction. Very bushy, complact grower. Flower large orchid pink. Very pretty. $18-24$ in. to $30-36$ in.

Ranny. Another Fruitland introduction. Good grower. Flower very light pink - just off white. Unusual. 18-24 in. to 3-4 ft.

Rosea. Tall grower; foliage dark green. Flower single, deep pink. Excellent material for screen. 18-24 in., 24-30 in., 30-36 in.

Showa-no-sakae. Low growing; double light pink flower. Spreading habit. 12-15 in. to 18-24 in.

Shi-shi-gashira. Low growing, spreading habit. Double deep pink flower. Another topnotch Sasanqua in its color. 12-15 in., 15-18 in.

Single White. Upright, compact grower. 24-30 in. to 3-4 $\mathrm{ft}$.

White Glory. Large, single white. Good. Good grower. $15-18$ in., $18-24$ in.

\section{PRICES ABOVE SASANQUAS:}

12-15 in.@\$.98 each; 3 or more@ @.90 each 15-18 in.@1.59 each;3 or more@1.49 each 18-24 in.@2.29 each; 3 or more@2.20 each 24-30 in.@2.98 each; 3 or more@2.90 each 30-36in.@3.98 each;3 or more@3.90 each 3-4 ft.@4.50 each;3 or more@4.40 each

\section{CANNAS - Perennial.}

King Humbert Red. Makes vivid color effect in summer. Excellent for massing.

King Humbert Yellow. Clear, bright yellow. Handsome green foliage.

Pink Hungaria. Comparatively dwarf grower. Prices above 3:

.25 each; 3 or more .20 each 
Castanea Mollissima (Chinese Chestnut). Small sized nut tree. Fruit tasty and good.

4-5 ft. $\$ 2.59$

5-6 ft. 2.98

Cedrus Deodara. Beautiful, graceful, blue-green conifer. Stately, majestic. Rapid grower. Good Christmas tree.

3-4 ft. $\$ 4.98$

$4-5 \mathrm{ft} . \quad 6.00$

$5-6 \mathrm{ft} . \quad 6.95$

$6-8 \mathrm{ft} . \quad 8.00$

Cedrus Libani. Dark green conifer, resembling Spruce. Large grower. Known in Biblical times.

18-24 in. $\$ 2.49$ each

$2-3$ ft. 3.98 each

Cephalotaxus Drupacea. Prostrate Japanese Yew. Graceful, feathery green foliage. Unusual. Different. Good for low massing effects.

$10-12$ in. $\$ 1.60$ each; 3 or more @ $\$ 1.50$ each 12-15 in. 2.00 each; 3 or more@ 1.90 each

\section{Cephalotaxus Harringtonia Fastigiata.}

Columna Yew. Compact, upright growth. Foliage dark rich green. Excellent for edging beds in shady locations.

12-15 in. \$1.59 each; 3 or more@\$1.49 each 15-18 in.2.00 each; 3 or more@1.90 each

Cercis Canadensis. Native red bud tree. Deciduous. Lilacpink flowers in early spring. Very hardy and showy. Medium height.

4-5 ft. $\$ 2.29$ each

$5-6 \mathrm{ft} . \quad 3.49$ each

6-8 ft. 3.98 each

Cercis Canadensis Alba. Unusual. White-flowering Judas tree. Very conspicuous in early spring when covered with pure white flowers.

$3-4$ ft. $\$ 5.00$ each

$4-5 \mathrm{ft}$. 6.00 each

$5-6 \mathrm{ft} . \quad 8.00$ each

Cercis Chinensis. Chinese red bud. Very bushy, semi-dwarf deciduous tree having large light pink flowers in profusion in early spring.

3-4 ft. $\$ 3.98$ each

4-5 ft. 5.00 each

$5-6 \mathrm{ft} . \quad 6.00$ each

Cestrum Nocturnum. Night-blooming jasmine. Not hardy outdoors. Good for greenhouse. Fragrant flowers produced at night in summer. Interesting. Graceful.

4 -inch pots $\$ 1.00$ each 
Chamaecyparis Obtusa Nana. Dwarf Japan Cypress. Beautiful, plume-like foliage. Dark Green. One of the most unusual conifers. Recommended to those who like the different. Will grow in partial shade or full sun. Hardy.

8-12 in. $\$ 1.00$ each; 3 or more @ \$.90 each 12-15 in. 1.75 each; 3 or more@ 1.65 each 15-18 in. 3.10 each; 3 or more@2.90 each 18-24 in. 3.59 each; 3 or more @3.49 each 24-30 in. 4.49 each; 3 or more@4.39 each 30-36 in. 5.00 each; 3 or more @ 4.80 each 3-4 ft.8.00 each; 3 or more@7.80 each

Chionanthus Virginica. Deciduous, flowering shrub commonly known as Grandaddy Graybeard. Distinctive shread-like white flowers in spring. 18-24 in. $\$ 1.59$ each

$2-3$ ft. 1.79 each

3-4 ft. 2.25 each

Clematis Mme. Edouard Andre. Large-flowered perennial vine. Large purplish-red flowers. Exotic. Plant on rose trellis for support.

Clematis Paniculata. Small white flowers in fall. Perennial. Fragrant.

Clematis Compte:

Clematis Crimson Star. Large red.

Clematis Duchess of Edinburgh. Magnificent double-white.

Clematis Henryi. Large, creamy-white flower's in summer.

Clematis Jackmani. Large flowered violet-purple. Most popular of all large-flowered varieties.

PRICES ABOVE 7 varieties: $\$ 1.29$ each

Clerodendron Thomsonae. Greenhouse plant with vine characteristics. Foliage dark green. Flowers white, tipped red. Unusual. Resembles bleeding heart. 4 -inch pot $\$ 1.00$ each

Cleyera Ochnacea. Handsome dark broad-leaved evergreen. Hardy; very colorful in spring and fall. Highly recommended. Moderate grower. $12-18$ in. $\$ 1.59$ each; 3 or more @ \$1.49 each 18-24 in. 2.49 each; 3 or more@2.39 each 2 -3 ft. 4.00 each; 3 or more @ 3.49 each 3-4 ft. 5.49 each; 3 or more@ 5.00 each 
Cornus Florida. White Dogwood. Deciduous. Blooms in early spring.

$2-3$ ft. $\$ 1.59$ each; 3 or more @ $\$ 1.49$ each 3-4 ft. 2.00 each; 3 or more@ 1.85 each 4-5 ft. 3.00 each; 3 or more@ 2.49 each 5-6 ft. 4.49 each; 3 or more@ 4.29 each 6-8 ft. 8.00 each; 3 or more@7.50 each 8-10 ft. 10.00 each; 3 or more@9.50 each

Cornus Florida Rubra. Pink Dogwood. Very beautiful shade of pink. Desirable and ornamental.

$2-3 \mathrm{ft}$. $\$ 3.00$ each

$3-4 \mathrm{ft} . \quad 4.00$ each

$4-5 \mathrm{ft} .5 .59$ each

Cornus Florida CHEROKEE CHIEF. New red-flowering Dogwood. Color more intense than the pink type.

$18-24$ in. $\$ 4.00$ each

$2-3$ ft. 5.00 each

Cortaderia Argentea (Pampas Grass). Hardy perennial, ornamental grass. Graceful foliage. Silvery plume-like flowers in summer. Grows in clumps.

Divisions $\$ 1.49$ each; 3 or more @ \$1.39 each

Cortaderia Argentea Rosea. Same as argentea, except plumes are light pink when first opening. Rare. Divisions $\$ 1.79$ each.

Cotoneaster Conspicua. New Cotoneaster with drooping foliage habit of growth. White flowers. Excellent for slope covering; low effects.

8-12 in. $\$ 1.00$ each

Cotoneaster Franchetti. Tall gray-green, graceful foliage. White flowers in spring, followed by russet berries in fall. Very good choice.

15-18 in. \$1.49 each; 3 or more @ \$1.39 each 18-24 in. 1.98 each; 3 or more@ 1.80 each $2-3$ in. 2.29 each; 3 or more @ 2.10 each 3-4 ft. 3.98 each; 3 or more@ 3.75 each

Cotoneaster Microphylla. Very small-leaved evergreen. Spreading, prostrate habit. Good for rockeries. $15-18$ in. in gallon cans@ @ $\$ 1.50$

Cryptomeria Japonica. Japan cedar. Tall, conifer tree. Stately; majestic. Foliage nice for floral arrrangements.

18-24 in.@\$2.00;3 or more@\$1.90 each

2-3 ft.@3.29; 3 or more@3.20 each

3-4 ft.@4.88; 3 or more@4.65 each

4-5 ft.@5.49; 3 or more@5.00 each

5-6 ft.@6.59; 3 or more@6.00 each

6-8 ft.@8.00;3 or more@7.50 each 
Cunninghamia Sinensis. Chinese Fir. Unusually attractive. Distinctive, ornamental foliage. A must for the arranger.

2-3 ft. @\$4.49

3-4 ft.@5.00

4-5 ft.@8.00

Cupressus Sempervirens Pyramidalis. Italian Cypress. Slender, pencil-like conifer. Attains height of 50-60 ft. Very formal.

$2-3$ ft. @\$2.59

3-4 ft. @3.59

Cydonia Niralis. White Flowering Quince. Deciduous flowering shrub. Very showy when in bloom in early spring. All sizes.

Cydonia Rosea. Flowers soft salmon-pink in early spring. 18-24 inch, 2-3 ft.

Cydonia Rubra. Flowers deep rosy-red. Makes good showing. 18-24 in., 2-3 ft. and 3-4 ft.

Above 3 Cydonias:

18-24 in.@\$1.00; 3 or more@\$.90 each 2-3 ft.@1.98; 3 or more@1.80 each

3-4 ft. @2.49; 3 or more@2.25 each

Daisy. Admiral Byrd. Very large white flowers. Perennial. Divisions@35c each;3 or more@30c each

Daphne Odora. An aristocratic evergreen. Low growing. Variegated green and white foliage. Very fragrant, pink flowers.

8-12 in.@\$2.98 each

Delphinium. Hardy Larkspur.

Belladonna. Spikes of clear turquoise blue blossoms in spring.

Divisions@47c each

Dianthus Plumarius. Hardy garden pinks. Pink. Perennial. Divisions@40c each

Elaeagnus Aurea Maculata. Russian Olive. Variegated, broad-leaved evergreen. Vine-like. Excellent for espaliering. Not common. Ideal for shady situations.

$12-15$ in. @ $\$ 1.48$

15-18 in. @2.00

18-24 in.@2.49

Elaeagnus Fruitlandi. Large, vigorous growing evergreen. Fragrant flowers; good for screening. Does well in shade or sun. Fruit edible.

$18-24$ in. @ $\$ 2.49 ; 3$ or more @ \$2.39 each $2-3$ ft. @ 3.59 ; 3 or more@3.25 each 
Elaeagnus Pungens. Large evergreen. Flowers extremely pungent; decorative foliage. Good.

18-24 in. @\$2.49; 3 or more@\$2.30 each

Elaeagnus Simoni. Round-leaf type. Very silvery-green foliage. Compact; desirable; large grower. 18-24 in.@\$2.49;3 or more@\$2.29 each 2-3 ft. @3.59; 3 or more@3.25 each

Eriobotrya Japonica (Espalier type). Japan Loquat. Oriental Plum tree. Evergreen. Very ornamental. Leathery, dark green foliage. Flowers fragrant in fall. Large grower.

4-5 ft.@\$5.00

5-6 ft.@6.49

6-8 ft.@10.00

Eucalyptus Cinera. Australian Gum tree. Large evergreen. Roundish, blue-green foliage, useful in floral arrangements. Different! Vigorous grower.

$12-18$ in. @ $\$ 1.98$

18-24 in.@2.49

Euonymus Patens. Semi-evergreen; medium height. Bushy in sun. Will tend to climb in shade. Very hardy.

18-24 in.@\$1.98; 3 or more@\$1.75 each

Exochorda Grandiflora (Pearl Bush). Deciduous flowering tree. White flowers in very early spring. Showy!

4-5 ft. @ \$3.00; 3 or more @ $\$ 2.90$ each 5-6 ft. @3.49; 3 or more@3.25 each

Fatshedera Lizei. New ivy-cross foliage, but bushy, upright growth. Ideal for protected, semi-shady or full sun places.

$8-12$ in. @ $\$ 1.00$

12-15 in.@1.49

Feijoa Sellowiana. South American Guava. Gray-green evergreen. Bushy. Beautiful, deep red flower produced in summer. Hardy and attractive. 18-24 in.@\$1.98; 3 or more@\$1.80 each 2-3 ft.@3.00;3 or more@2.75 each 3-4 ft.@3.49;3 or more@3.20 each

Ficus Repens. Climbing Fig. Rapid growing evergreen vine. Clings to any surface. Small foliage. Neat; tidy and very satisfactory.

Each 35c; 3 or more @ 30c each

Figs. Black Ischia. Dark. Flavor good.

Figs. VBrown Turkey. Largest brown fig available.

Figs. Celeste. Sugar Fig. Sweet, medium size. Very hardy. 
Figs. Green Ischia. Green skin. Good.

Figs. White Genoa. White Fig. Lemon-yellow when ripe. Good.

Price above Figs:

18-24 in.@\$1.29

2-3 ft.@1.49

Forsythia Spectabilis. Golden Bell. One of the best varieties. Large yellow flowers early spring. Medium height.

2-3 ft.@\$1.00

3-4 ft.@1.35

4-5 ft.@1.49

Gardenia Florida. Cape Jasmine. Beautiful dark green, bushy, evergreen. Wax-like, fragrant flowers in summer. Old fashioned. $12-18$ in. and 18 . 24 in.

Gardenia Fortunei. Similar to above. $12-18$ in. and 18-24 in.

Gardenia Mystery. One of the newer varieties. Flowers larger than above. 12-18 in. only.

Prices above 3 Gardenias:

12-18 in.@\$.78; 3 or more@\$.75 each 18-24 in.@1.50;3 or more@1.30 each

Gardenia Radicans. Trailing variety. Low-spreading growth. Foliage glossy, dark green. Compact. Ideal. Small white flowers with same Gardenia fragrance as others.

10-12 in.@\$1.49; 3 or more@ @1.35 each

Gelsemium Sempervirens. Carolina Jessamine. Evergreen vine. Native. Fragrant yellow flowers in the spring. Rampant grower.

Clumps@\$1.00;3 or more@90c each

Gelsemium Sempervirens Flore Plena. Double yellow flowers. Rare

Clumps@\$1.29

Geraniums: Lemon - Nutmeg - Rose.

From pots@75c

Gerbera Jamesoni. Transvaal Daisy. Exotic. Hardy perennial. Very attractive. Pastel shades. Excellent for massing in partial shade.

Each@40c; 3 or more@35c each

Ginkgo Biloba. Maiden Hair tree. Deciduous. Foliage similar to maiden hair fern. Fan-like. Very conspicuous, foliage turns brilliant yellow in fall. 2-3 ft.in cans@ @ $\$ 2.00$ 
Gloriosa Rothschildiana. Climbing perennial Lily. Exotic. Unusual coloring. Form similar to common tiger, lily. Color changes from red to orange and yellow.

Tubers@\$1.00

Gordonia Alatamaha. Deciduous small tree. Large sweetscented flowers. Very rare and desirable.

18-24 in.@\$3.50

$2-3$ ft. @4.50

Gordonia Lasianthus. Loblolly Bay. Large growing evergreen tree. Fragrant white flowers in summer. Slow growing. Beautiful tree for the home.

18-24 in.@\$2.00

2-3 ft.@3.00

Grapes: (bunch type)

7 Caco. Sweet red. Good quality.

7 Concord. Blue-black. Good wine grape.

Delaware. Red. Prolific.

Fredonia. Blue-black. Large clusters. Good quality.

7 Golden Muscat. Golden-brown. Very good, musky flavor. Good quality.

$>$ Niagara. White - sweet and desirable.

Prices above 6 Grapes:

@50c;3 or more@40c each

Grapes: (Muscadine type)

7 Dulcet. Reddish-purple. Good flavor. Diseaseresistant.

- Flowers. Black. Sweet. Ripens Sept.-Oct.

Hunt. Black. Vigorous grower. Good flavor. Aug'ust.

James. Black. Juicy. Ripens after Scuppernong.

7 Male. Use 1 to every 4 vines for good production.

$\rightarrow$ Nevermiss (Patent). Larger than Scuppernong. Bronze berries. Sweet, vinous and pulpy $90 \mathrm{c}$ each

Scuppernong. Amber colored; old fashioned; excellent flavor. Ideal for arbor. Use 1 male vine to every 4 scuppernongs.

1 Spalding. Blue-black. Ripens 2 weeks later than Hunt. Excellent quality.

$\checkmark$ Thomas. Violet. Tender and sweet. August.

Willard. Bronze. Will help pollenize other varieties and is also edible and most desirable. Comparatively new.

Prices of Muscadine types (except Nevermiss):

@65c;3 or more@50c each 
Gypsophila. Baby's Breath.

Bristol Fairy. Perennial with very dainty small white flowers in summer.

@ $\$ 1.00$ each

Hedera. Ivy. Evergreen. Excellent ground cover or vine.

Algeriensis. Very large-leaved. Good wall covering.

Guignard. Large, leathery foliage. Different. Good.

Helix. Common English Ivy.

Helix Variegated. Variegated form. Slightly smaller foliage than the green form.

Merion Beauty. Dainty, small-leaved Ivy. Hardy. Decorative.

Prices above Ivy $15 c$ each

Hedychium Coronarium (Butterfly Lily). Tuberous rooted plant. Cluster of fragrant white flowers. Gardenia scented. Good floral arrangement material $85 \mathrm{c}$ each

Hemerocallis : (Daylily)

Ajax. Evergreen. Deep yellow.

Amaryllis. Deep yellow. Evergreen. Medium height.

Bagdad. Tall. Orange-red and yellow. Evergreen. June-July.

Citrina. Sulphur yellow.

Dorothy McDade. Chartreuse. Evergreen. Very good.

Dumortiere. Cadmium yellow. May-June.

E. A. Bowles. Carrot-red; very large flower.

Florham. Golden-yellow. Medium height. Evergreen. June.

Goldeni. Deep golden-yellow. Large flower. Medium height. June-July.

Imperator. Orange-red with yellow throat. Tall.

Lemon King. Large lemon-yellow. Medium height. Good.

Mikado. Rich yellow with large mahogany spot on each petal. Usually blooms a second time.

Queen of Gonzales. Large, rich yellow. Prolific and showy. Evergreen.

The Gem. Rich yellow. Medium height. Evergreen. July.

Thunbergi. Pale yellow. Low.

Prices above Hemerocallis:

Divisions@50c;3 or more@40c each 
Hibiscus Sinensis. Florida Hibiscus. Not hardy outside.

American Beauty. Large, ruffled red. Exotic.

Double Red. Ruffled, full. Very showy.

Double Salmon.

Double Yellow. Rare. Resembles Camellia japonica. Scarce.

Single Pink. Nice pink.

Single Salmon. Beautiful soft salmon tone. Prices above Hibiscus $\$ 1.00$

Hibiscus Syriacus. Althea or Rose of Sharon.

Double Light Pink. Not common. Very light, double pink, resembling a Debutante Camellia. Scarce.

Rubus. Deciduous tree. Profuse bloomer. Easy to grow. Red flowers.

Prices above two Hibiscus:

18-24 in.@\$.75; 3 or more@\$.65 each 2-3 ft.@1.00; 3 or more@.90 each

Hosta. Funkia. Hardy perennial; low growing and can be used as ground cover in deep shade.

@ 75c each

Hydrangea Opuloides. Blue or pink. Common, deciduous hydrangea. Nice for shady, damp places. Soil determines color of bloom.

12-15 in.@\$1.00

Hydrangea P.G. Tree Hydrangea. Deciduous. Large white trusses of flowers in summer.

$12-15$ in. @ $\$ 1.29$

Iberis Sempervirens. Candytuft. Evergreen. Low, compact, perennial. Dark green foliage. White flowers in profusion in early spring. Each $35 \mathrm{c}$

Ilex Cassine Angustifolia. Tall upright growing Holly. Red opaque berries in profusion on good size plants.

3-4 ft. @\$4.49;3 or more@\$4.00 each 4-5 ft.@5.98; 3 or more@5.50 each 5-6 ft. @6.75; 3 or more@6.25 each 6-8 ft. @10.00;3 or mroe@9.50 each 8-10 ft.@25.00; 3 or more@23.00 each

Ilex Convexa. Dwarf evergreen holly. Shiny, small leaves. Resembles boxwood. Medium height. A good plant.

10-12 in.@\$1.98; 3 or more@ @1.75 each 12-15 in.@2.50; 3 or more@2.25 each 15-18 in. @ 3.00; 3 or more@2.75 each 18-24 in.@3.49; 3 or more@3.25 each

Ilex Cornuta. Horned Holly. Very spiny, attractive growth.

Compact. Large red berries. 
Ilex Cornuta Burfordi. One of the most popular hollies grown. Glossy, green leaves. Compact, rapid growth. Very large red berries in profusion.

Prices above 2 Hollies:

10-12 in.@\$1.00; 3 or more@\$.90 each 12-15 in.@1.59;3 or more@1.40 each 15-18 in.@2.75; 3 or more@2.25 each 18-24 in.@3.00; 3 or more@2.75 each 2 -3 ft. @ 5.00; 3 or more @4.50 each 3-4 ft.@15.00

$4-5$ ft. @25.00

Ilex Crenata. Japanese dwarf holly. Small dark green foliage. Can be clipped to resemble boxwood. Excellent for partial shade.

$12-15$ in. @ $\$ 1.75 ; 3$ or more @ $\$ 1.50$ each

Ilex Crenata Major. Large leaf Japanese holly. Evergreen. Very good grower. Compact; medium height; berries black.

8-12 in.@\$1.59; 3 or more@ @1.39 each 12-15 in.@1.98; 3 or more@1.80 each 15-18 in.@2.75; 3 or more@2.50 each 18-24 in.@3.59; 3 or more@3.39 each

Ilex Helleri. New dwarf Japanese holly. Evergreen. Very small foliage; compact; highly recommended. Different. Hardy.

10-12 in. @ \$2.29; 3 or more@ @2.25 each

Ilex Integra. A shade-loving plant. Dark green foliage. Unusual. No berries.

18-24 in. @ \$2.00; 3 or more@ @1.85 each 2 -3 ft.@3.00; 3 or more@2.85 each

Ilex Latifolia. Magnolia leaf holly. Majestic. Beautiful. Resembles Southern Magnolia in form. Large clusters of red berries in winter. Most desirable.

15-18 in.@\$2.75

18-24 in.@3.00

2-3 ft.@5.00

Ilex Opaca - East Palatka. Native hybrid holly. Bright green foliage. Bushy growth. Small red berries in winter. Very hardy. Excellent screen plant.

18-24 in.@\$1.49; 3 or more @ \$1.39 each 4-5 ft. @ 5.75; 3 or more@ 5.50 each 5-6 ft. @10.00; 3 or more@9.50 each 6-8 ft.@25.00 
Ilex Opaca Howardi. Beautiful, rare, dark green foliage. Stately; attractive. Red berries in winter. Handsome.

2-3 ft. @ \$3.59; 3 or more@\$3.39 each 4-5 ft.@5.75; 3 or more@5.25 each 5-6 ft.@10.00; 3 or more@9.50 each 6-8 ft.@20.00

Ilex Opaca. Native evergreen holly. Makes for a cheery appearance in winter when red berry ushers in the Christmas season.

3-4 ft.@\$4.95;3 or more@\$4.75 each 4-5 ft.@5.95; 3 or more@5.50 each 5-6 ft.@10.95; 3 or more@9.95 each 6-8 ft.@20.00

Ilex Pernyi. Very ornamental Chinese Holly. Unusual foliage formation. Different. Berries red. Conspicious. New! Desirable.

10-12 in.@\$1.50

12-15in.@1.98

15-18 in.@2.45

Ilex Vomitoria. Native evergreen holly. Medium height. Thrives in almost any situation. Very hardy and rugged. Prolific crops of red berries.

3-4 ft. @\$3.98; 3 or more @\$3.75 each 4-5 ft.@5.00;3 or more@4.50 each

Ilex Xanthocarpa. Rare YELLOW BERRIED holly. Foliage similar to opaca.

2-3 ft.@\$3.50

Illicium Anisatum. Evergreen. Medium height. Bright green foliage. Does well in shade or full sun. Foliage aromatic. Good screen material.

18-24 in. @ \$1.50;3 or more@\$1.40 each 2-3 ft. @2.98; 3 or more @2.75 each 3-4 ft.@ $@ 3.49 ; 3$ or more@3.29 each

Ipomoea Leari. Perennial Morning Glory. Rapid growing vine. Large dark blue flowers remain open all day. No seed.

Tubers@75c

Iris Germanica:

Black Banner. Black velvet.

Black Magic. Blue-violet. Spring and fall bloomer.

Blue Monarch. Tall blue.

Buffawn. Light fawn and buff. 
California Gold. Very large, deep yellow.

Cloth of Gold. Brilliant deep yellow.

Ethelwynn Dubuar. Deep self-pink. Tall.

Garden Flame. Garnet red. Golden yellow beard.

Golden Spike. Outstanding golden-yellow; heavy orange-yellow beard.

Gudrun. Early white with light gold beard. Semi-dwarf.

Happy Days. Large yellow. Good.

Imperial Blush. Very large, soft pink.

Indian Hills. Rich true purple.

King Juba. Large old gold with mahogany falls.

Kochi. Rich, claret purple.

Minnie Colquit. Pearly white, blueish purple stipple border.

Moonlight. Very light blue - almost white.

Pink Cameo. True flamingo pink with a startling tangerine beard.

Pink Opal. Tall, uniform pink tones.

Pink Satin. Orchid pink.

Pink Talcum. Peach blossom pink with reddish beard. 46 iıı.

Pinnacle. Clear white standards; primrose yellow falls. Wax-like and beautifully molded.

Pluie d'Or. Light, clear yellow. Tall.

Prairie Sunset. Sunset effect.

Rameses. Blending pink and yellow with pronounced yellow glow at center.

Red Radiance. Rich glowing red.

Rodeo. Large. Standards gold; falls white, edged gold with brown markings.

San Francisco. White with feather stitch edging of blue.

Solid Mahogany. Large, rich, brownish-red.

Theodolinda. White with feather stitch edging of lavender-blue.

Prices above Iris Germanica@75c each

Ixora. Pot plant. Dark glossy green foliage. Clusters of salmon colored star-shaped flowers in summer. Rare. Attractive.

5-inch pot@\$1.00

Jasminum Beesianum. Deciduous shrub growing about $3 \mathrm{ft}$. Has pink or deep rose, very fragrant flowers, in summer.

$18-24$ in. @ $\$ 1.00$ 
Jasminum Grand Duke. Fragrant, summer flowering pot plant.

5-inch pot@\$1.00

Jasminum Stephanense. Hardy at Philadelphia. Semi-climbing. Fragrant, pale pink flowers late April. 18-24 in. @ $\$ 1.00$

Juniperus Chinensis Albo-Variegata (Whiteleaf Chinese Juniper). Compact, cone-shaped plant attaining height $10 \mathrm{ft}$. Foliage beautifully variegated green and white.

15-18 in.@\$1.49

18-24 in.@2.49

24-30 in.@3.00

30-36 in.@4.00

Juniperus Chinensis Conferta. Beautiful, bright green, trailing. Height 18 inches. Spreading habit; excellent for massing on slopes.

$18-24$ in. @ \$2.49; 3 or more @ \$2.29 each 24-30 in.@3.49; 3 or more@3.29 each

Juniperus Chinensis Foemina. Chinese Juniper. Tall conical form. Gray-green foliage.

2-3 ft.@\$2.50

3-4 ft.@2.98

4-5 ft.@3.85

5-6 ft.@5.98

6-8 ft.@7.00

Juniperus Chinensis Fruitlandi. Sport of J. pfitzeriana. Foliage resembles J. foemina.

$15-18$ in. @ $\$ 2.00 ; 3$ or more @ $\$ 1.90$ each 18-24 in.@2.98; 3 or more@2.75 each 24-30 in.@3.79; 3 or more@3.59 each 30-36 in.@5.00; 3 or more@4.50 each

Juniperus Chinensis Pfitzeriana. Spreading type with graygreen foliage. Very hardy; medium height. A good practical Juniper.

18-24 in.@\$2.49; 3 or more@\$2.29 each 24-30 in. @3.49; 3 or more@3.29 each 30-36 in. @4.49; 3 or more@4.29 each

Juniperus Chinensis Sargenti. Trailing habit. Foliage bluegray. Maximum height $2 \mathrm{ft}$. Spreading habit. Attractive.

12-15 in. @ \$1.49; 3 or more@ @1.29 each 15-18 in.@2.00; 3 or more@1.75 each 18-24 in. @2.98; 3 or more@2.75 each 24-30 in.@3.79; 3 or more@3.49 each 
Juniperus Chinensis Stricta. Conical; compact growth. Moderate height.

2-3 ft. @ $\$ 3.98$

3-4 ft.@5.00

4-5 ft.@5.49

5-6 ft.@6.00

Juniperus Communis. Tall pencil-like form. Foliage compact; g'ray-green. Very formal. Does best in full sun.

8-10 ft. @\$10.00

10-12 ft. @12.00

Juniperus Communis Ashfordi. Low growing pencil-like conifer of good use. Foliage bluish-green. Ultimate height 6 to $7 \mathrm{ft}$.

18-24 in. @ \$1.49; 3 or more @ \$1.39 each 2-3 ft.@2.59; 3 or more@2.49 each $3-4$ ft. @ 3.29 ; 3 or more @3.00 each

Kadsura. Japanese evergreen vine. Prefers shady location. Good trellis plant.

Gallon cans@\$1.00

Kerria Japonica fl. pl. Deciduous; double yellow flowers in spring. Very colorful.

18-24 in.@\$1.00; 3 or more@90c each

Koelreuteria Paniculata. Golden Rain Tree. Small sized shade tree. Golden yellow flowers in early summer, followed by seed pods which are very useful in flower arranging. Very ornamental.

$4-5$ ft. @ $\$ 2.79$

5-6 ft.@2.98

Kolkwitzia. Beauty Bush. Has general resemblance to Weigela. Trumpet-shaped, pale pink flowers in April. Buds darker. Deciduous.

$4-5 \mathrm{ft}$. @ $\$ 3.00$

5-6 ft.@5.00

Lagerstroemia. Crape Myrtle.

Carolina Beauty. Deciduous. Best deep red yet produced. $18-24$ in. to $5-6 \mathrm{ft}$.

Pink. 3-4 ft, 4-5 ft.

Purple. 3-4', 4-5', 5-6'.

White. 2-3', 3-4', 4-5', 5-6'.

Prices above Lagerstroemia:

18-24 in. @ \$1.49; 3 or more@ @1.29 each 2-3 ft. @1.98; 3 or more@1.75 each 3-4 ft. @2.50; 3 or more@2.25 each 4-5 ft. @2.98; 3 or more@2.75 each 5-6 ft. @3.98; 3 or more@3.75 each 
Lantana Delicatissima. Trailing perennial, having lavender flowers late summer to frost. Should be planted in April.

From pots $50 \mathrm{c}$

Laurocerasus Caroliniana. Cherry Laurel. Evergreen. Can be kept trimmed to any shape or size desired. Very useful.

*15-18 in.@\$.50; 3 or more@ @.40 each *18-24 in.@1.49; 3 or more@1.29 each † 2-3 ft.@3.90; 3 or more@3.75 each † 4-5 ft.@4.49; 3 or more@4.29 each † 5-6 ft.@7.95; 3 or more@7.50 each $\dagger 6-8$ ft. @10.00

*Bare root; †balled and burlapped.

Laurocerasus Officinalis. English Laurel. Large leaf evergreen.

18-24 in.@\$1.98; 3 or more@\$1.75 each

Ligustrum Japonicum. Low-growing evergreen with white flowers.

15-18 in. @ \$1.29; 3 or more@ @1.20 each 18-24 in.@1.98; 3 or more@1.80 each 24-30 in.@2.69; 3 or more@2.49 each 30-36 in.@2.98; 3 or more@2.78 each 3-4 ft. @ 4.49; 3 or more@4.29 each 4-5 ft. @ 5.49; 3 or more@ 5.29 each 5-6 ft. @6.49

Ligustrum Lucidum. Tall growing evergreen, useful for screening.

*18-24 in. @\$.79; 3 or more@\$.69 each

*2-3 ft. @1.49; 3 or more@1.29 each

† 3-4 ft. @2.79; 3 or more@2.59 each

† 4-5 ft. @3.98; 3 or more@3.75 each

*Bare root; †balled and burlapped.

Liriodendron Tulipifera. Tulip Poplar.

Tall, deciduous tree. Pyramidal form. Large leaves. Greenish, tulip-shaped flower.

5-6 ft. @ $\$ 2.59$

6-8 ft.@3.49

Liriope Japonica. Dwarf evergreen. Very small, narrow foliage. Height 4 to 6 in. Fine for borders and rockeries.

Divisions@15c; 3 or more at $12 \frac{1}{2} \mathrm{c}$ each

Liriope Muscari. Evergreen; stemless. Blue flowers in spikes in July, followed by black berries. Ideal ground cover.

Divisions@15c;3 or more at $12 \frac{1}{2} \mathrm{c}$ each 
Liriope Spicata. One of the best for ground carpet under trees and in shade. Spikes of white to violet color in July. Rapid grower.

Divisions@10c;3 or more@8c each

Lonicera Browni. Honeysuckle. Evergreen with orangescarlet flowers in April. Vine. $\$ 1.00$

Lonicera Fragrantissima. Deciduous shrub, having fragrant creamy white flowers in January.

$18-24$ in. @ $\$ 1.00 ; 3$ or more @ 90c each

Lonicera Halliana. Native, evergreen honeysuckle. Fragrant creamy-white flowers in summer and fall. Good for ground cover or trellis.

Divisions@50c

Lonicera Heckrotti. Rose-colored flowers on outside, yellow in center. Blooms continuously from spring until fall. Evergreen.

Vine@\$1.00

Lonicera Sulphurea. Evergreen with yellow flowers in April. Rare.

@ $\$ 1.50$

Lorapetalum Chinensis. Evergreen. White flowers in spring, resembling Witch Hazel.

18-24 in. @ \$2.49; 3 or more@\$2.39 each 2-3 ft. @4.00;3 or more@3.75 each 3-4 ft. @ 5.00; 3 or more@4.50 each

Magnolia Grandiflora. The grandest of all our native broadleaved evergreen trees. Fragrant, large, white flowers in May and June.

$\dagger 18-24$ in. @ \$2.00; 3 or more @\$1.85 each † 2-3 ft.@ $@ 3.00$; 3 or more@2.75 each

†3-4 ft.@4.00; 3 or more@3.75 each

† 4-5 ft.@5.49;3 or more@5.29 each

†5-6 ft.@8.75;3 or more@8.50 each

$+6-8$ ft. @12.50

† 8-10 ft.@25.00

$\dagger$ Balled and burlapped.

Magnolia Liliflora. Chinese Magnolia. Deciduous; small tree, having large purple and white flowers late March before leaves appear.

18-24 in., 2-3 ft., 3-4 ft., 4-5 ft., 5-6 ft.

Magnolia Liliflora Nigra. Chinese Magnolia. Deep, purplish-red flowers before leaves appear in the spring

18-24 in., 2-3 ft., 3-4 ft., 4-5 ft., 5-6 ft. 
Magnolia Soulangeana. Chinese Magnolia. Large pale pink flowers in early spring before leaves appear. First to bloom.

18-24 in., 2-3 ft., 3-4 ft., 4-5 ft., 5-6 ft., 6-8 ft. Prices above Magnolias:

18-24 in.@\$2.75; 3 or more@\$2.50 each 2-3 ft.@3.25; 3 or more@3.00 each 3-4 ft.@4.00;3 or more@3.75 each 4-5 ft.@5.00; 3 or more@4.75 each 5-6 ft.@8.00;3 or more@7.50 each 6-8 ft.@12.50; 3 or more@12.00 each 8-10 ft.@25.00

Magnolia Stellata. Star Magnolia. Shrub or small deciduous tree. Very fragrant, star-shaped white flowers in spring.

18-24 in.@\$3.00

Mahonia Bealei. Evergreen, known as Holly Grape. Unusual foliag'e. Yellow flowers in spring, followed by clusters of purple berries. Likes shady locations.

8-12 in.@\$1.50;3 or more@\$1.35 each 12-15 in.@1.79; 3 or more@1.59 each 15-18 in.@2.49; 3 or more@2.29 each 18-24 in.@3.00; 3 or more@2.75 each 2-3 ft.@3.49; 3 or more@3.29 each 3-4 ft.@4.49;

Malus Eleyi. Flowering Crab. Purple or red-leaf, having clusters of pink flowers in spring, followed by showy purple-red fruit. 3-4 ft., 4-5 ft.

Malus Hopa. Rose pink flowers, followed by fruit that is red inside and out. Strong, healthy, upright, deciduous tree. 3-4 $\mathrm{ft}$., 4-5 ft.

Prices above two Malus:

3-4 ft.@\$2.50

4-5 ft.@2.75

Melia Azadarach Umbraculiformis. Texas Umbrella. Resembles gigantic umbrella. Rapid grower; dense foliage. Fragrant, purple flowers in April. Good for play yard or kennel.

5-6 ft.@\$3.79

6-8 ft.@5.00

Meratia Praecox. Deciduous flowering shrub of medium height. Very fragrant flowers in dead of winter. Desirable. Unusual.

18-24 in.@\$1.50

2-3 ft.@2.25 
Mint. Foliage used for flavoring drinks or foods.

Clump@25c

Moraine Locust. Deciduous shade tree. Good grower. Compound foliage; long lived; disease-resistant. Desirable.

6-8 ft. @ $\$ 10.00$

Nandina Domestica. Heavenly Bamboo. Evergreen, medium height. White flowers in spring, followed by clusters of red berries which hang on all winter.

$12-15$ in. @ $\$ 1.49 ; 3$ or more @ \$1.29 each 15-18 in. @1.85; 3 or more@1.65 each 18-24 in. @2.25; 3 or more@2.00 each 2-3 ft. @3.49; 3 or more@3.29 each $3-4$ ft. @5.00

Nerium. Oleander. Evergreen, growing up to $15 \mathrm{ft}$. Flowers from April throughout summer.

Cardinal. Red

Double Red.

Double Peachblow.

Mme. Peyre. Pale flesh.

Prof. Parlartorre. Pink. Double corolla.

Single White.

@ 1.49 each; 3 or more @ \$1.29 each

Ophiopogon Jaburan Vittata. Snakebeard. A grass-like plant, having long, narrow, green and yellow foliage. Blue flowers in late summer. Good for borders.

Divisions@50c

Osmanthus Fortunei. Hollyleaf Tea Olive. Dark green, spiny-toothed foliage, resembling holly. Very fragrant white flowers in fall. Evergreen. 15-18 in. to 30-36 in.

Osmanthus Fragrans. Tea Olive. Small, fragrant, white flowers in clusters several times a year. Blooms young. Evergreen.

Prices above two Osmanthus:

15-18 in. @ \$1.85; 3 or more@ @ $\$ 1.75$ each 18-24 in.@2.59; 3 or more@2.49 each 24-30 in.@3.59; 3 or more@3.49 each 30-36 in.@4.00; 3 or more@3.50 each

\section{PEACHES}

Belle. July 5-20

Carman. June 20-July 1

Dixie Gem. July 1

Elberta. Mid. July

Golden Jubilee. Mid. Season

J. H. Hale. Mid. to last of July 
Hiley. June 25-July 5

$>$ Mayílower. May 15-June 1

- Southland. June 25-July 5

Prices: $3-4 \mathrm{ft}$. $-69 \mathrm{c}$ each

$4-5 \mathrm{ft} .-79 \mathrm{c}$ each

Pears.

Baldwin. Good flavor, vigorous grower. Ripens in August. Said to be blight-resistant.

7 Garber. Resembles the Kieffer in size, appearance and quality. A thrifty grower and valuable variety. August.

Kieffer. Fruit large. Skin yellow, with a light vermillion cheek; flesh brittle, very juicy. Begins to bear when four years old. September, October.

Le Conte (Chinese Pear). Fruit large; pale yellow; quality variable. Begins to bear at 5 years old. July 20 to end of August.

$>$ Orient. New. One of the best for the South. Fruit $3^{1 / 4}$ " $\times 3^{1 / 4}$ "; uniform in size, skin thick, lemon-yellow mottled with russet dots. Flesh creamy-white; juicy; sweet; subacid. Fine for canning. Said to be blight-resistant. 4-6 ft.@\$1.79 each

Pecans.

Mahan. Largest and thinnest shell on market. Top quality. Good bearer.

3-4 ft. @\$4.00; 3 or more@ @3.95 each

Schley. One of the old varieties. Thin shell. Good flavor.

-Stuart. The old reliable. Produces under all conditions. Full meat and prolific. Disease resistant.

Prices above two:

$3-4$ ft. @ $\$ 2.59 ; 3$ or more @ $\$ 2.49$ each

4-5 ft. @2.85; 3 or more@2.75 each

5-6 ft.@3.25; 3 or more@3.15 each

Persimmons. Japanese.

Very large fruit - showy and delicious.

$>$ Fuyugaki. Medium to large; deep red skin; light flesh, non-astringent. Very sweet and may be used while still hard. Seedless. September-October.

$>$ Tane-Nashi. Very large, light yellow, changing to bright red. Flesh yellow. Seedless. Prices above two Persimmons:

3-4 ft.@\$1.59

4-5 ft.@2.25

Phajus Grandifolius. Veiled Nun Lily. Pot plant. A form of orchid. Exotic, different and desirable.

Pot@\$3.00 
Philadelphus Virginial. Deciduous, flowering shrub of medium height. Fragrant, white flowers early spring.

2 -3 ft. @ $\$ 1.50 ; 3$ or more @ $\$ 1.40$ each $3-4$ ft. @1.75; 3 or more @ 1.55 each

Philodendron Selloum. House or conservatory plant. Large, beautiful foliage. Gives that tropical look to the house. Very decorative.

18-24 in.@\$3.50

Phlox Subulata. Moss Phlox. Good for borders or rockeries. Blue, Rosea.

Divisions@\$1.50 per doz.

Photinia Glabra. Evergreen. Medium grower. Excellent for formal effect, as it can be kept clipped, and new foliage is always red.

$12-18$ in. @ $\$ 1.59 ; 3$ or more @ $\$ 1.39$ each 18-24 in.@2.59; 3 or more@2.35 each 2-3 ft.@3.00;3 or more@2.75 each 3-4 ft.@3.79;3 or more@3.50 each

Photinia Serrulata. Large, evergreen foliage. White clusters of flowers in spring. Russet clusters of berries in fall. Thrives in full sun or shade. Excellent screen material.

2-3 ft. @\$3.00; 3 or more@\$2.75 each 3-4 ft. @4.49; 3 or more@ 4.29 each 4-5 ft. @5.59; 3 or more@ 5.29 each

Pinus Caribaea. Slash Pine. Beautiful long needles. Rapid grower. Grown in cans - transplant easily. 2 -3 ft.@\$1.98; 3 or more@ @1.75 each 3-4 ft. @3.00; 3 or more @2.75 each 4-5 ft.@4.00

Pittosporum Tobira. Large evergreen; compact growth; spreading habit. Foliage glossy green. Fragrant, creamy-white flowers. Excellent.

15-18 in.@\$2.25

18-24 in.@2.98

24-30 in.@4.25

30-36 in.@6.00

Pittosporum Tobira Variegata. Medium height evergreen. Very compact growth. Foliage pale green and white. Good contrast for dark background.

$8-12$ in. @ $\$ 1.50$

12-15 in.@2.00

15-18 in.@2.25

18-24 in.@2.98

Plumbago Blue. Deciduous. Lovely pale blue flowers. Can be grown in pots or open ground. 
Plumbago White. Same as above, except flowers are white. Pots@65c

Plums.

Ybundance (Yellow-fleshed Botan). Yellow, heavily washed purple-carmine; flesh firm, juicy, with apricot flavor. Clingstone. One of best early varieties. June 15 to July 5 .

$>$ Burbank. Cherry-red mottled yellow; flesh, flavor and quality are identical with Abundance. July 15 to 31 .

Combination. Large, early, light crimson plum of very best quality. Flesh light yellow, nearly freestone. June 5-15.

- Methley. Red-fleshed, red-skinned variety of very good quality. Sweeter than many plums. One of the best. May 15 to 30 .

Ogon. Large, greenish-yellow. Firm, sweet. Good.

Red Nagate (Red June). Skin purplish-red; flesh yellow, solid, somewhat coarse-grained: juicy, subacid. Damson flavor. Ripens a week before Abundance.

Satsuma, or Blood Plum (Yonemono). Large, dark purplish-red. Flesh firm, juicy, dark red or blood-color, well-flavored. Unsurpassed for canning. Mid-July.

$>$ Wickson. Fruit large, waxy white, changing to crimson-purple; flesh firm, yellow, juicy, subacid and highly flavored; pit small; clingstone. July 10 to 25 .

4-6 ft. @\$1.80; 3 or more @\$1.75 each

Podocarpus Maki (Japanesa yew). Upright grower; dark green foliage. Most desirable. Foliage used extensively in flower arrangements.

8-12 in. Gal. cans $\$ 1.50$ each

18-24 in. Gal. cans 5.00 each

Populus Nigra Italica. Lombardy Poplar. Deciduous. Slender, columnar type. Ideal for formal effects and screening tall buildings.

5-6 ft. @ \$1.98; 3 or more@ @1.75 each

6-8 ft. @ 3.79 ; 3 or more@3.50 each

8-10 ft.@4.49; 3 or more@4.00 each

10-12 ft.@5.50; 3 or more@5.00 each

Populus Simoni Fastigiata. Simon Popular. Resembles the Lombardy, but making a more pleasing impression. Rapid grower.

4-5 ft. @\$1.49; 3 or more@\$1.29 each

Prunus Campanulata. Flowering Cherry. Deciduous. One of first to bloom in spring. Deep cerise flowers in January and February before leaves appear.

4-5 ft. @ $\$ 3.00$ each 
Prunus Kwanzan. Japanese Flowering Cherry. Very large, double, light pink flowers about size of a quarter. Dainty. Medium height.

4-5 ft.@\$3.98 each

Prunus Thundercloud. Purple-leaf Plum. Deciduous. Deep reddish-purple foliage throughout summer. Very showy.

4-5 ft.@\$1.85 eầch

Punica Alba. White Flowering Pomegranate. Deciduous, small tree. White flowers in summer resemble carnations.

18-24 in.@\$1.00 each

$2-3$ ft. @\$1.49 each

Punica Rubra. Red Flowering Pomegranate. Very ornamental.

2-3 ft.@\$1.49 each

Punica Variegated. Flowers pink and white.

18-24 in. @\$1.00 each

2-3 ft.@1.40 each

3-4 ft. @1.75 each

Pyracantha Formosana. Large growing evergreen, with conspicuous large red berries in profusion in fall.

18-24 in., bare root, cut back

@ $\$ 1.00$ each; 3 or more @ $\$ .90$ each

2-3 ft., bare root, cut back

@ $\$ 2.00$ each; 3 or more @ $\$ 1.75$ each

Gallon cans@\$1.79 each

3-gallon cans@\$2.79 each

Quercus Alba. White Oak. Stately; very ornamental. Silvery-gray bark. Deciduous. Majestic!

4-6 ft., bare root@\$3.75 each

6-8 ft., bare root@5.00 each

8-10 ft., bare root@7.00 each

10-12 ft., bare root@8.00 each

Quercus Darlington. Evergreen Oak. Broad, spreading head. Rapid grower. Good shade tree.

4-5 ft., B\&B@\$4.00 each

5-6 ft., B\&B@6.00 each

6-8 ft., B\&B@8.00 each

8-10 ft., B\&B@10.00 each

10-12 ft., B\&B@15.00 each

Quercus Glauca. Japanese Evergreen Oak. Large green leaves year round. Nice broad crown. Makes beautiful shade tree. Rapid growth.

4-6 ft.@4.00 each; 3 or more@\$3.50 each 
Quercus Phellos. Willow Oak. Deciduous. Long, narrow, willow leaves. Moderate grower. Good shade tree

6-8 ft.@\$5.00 each

8-10 ft.@7.00 each

10-12 ft.@8.00 each

Quercus Rubra. Red Oak. Deciduous. Very colorful in fall. Good shade tree.

6-8 ft.@\$5.00 each

8-10 ft.@7.00 each

10-12 ft.@8.00 each

Quercus Suber. Cork Oak. Rare, evergreen type. Slow growth. Actual cork-producing bark. Unique. 18-24 in.@\$2.59 each

2-3 ft.@3.49 each

Quercus Virginiana. Like Oak. Evergreen. The monarch of the Oaks. Graceful, spreading branches. Slow grower. Lovely!

$\begin{array}{cccc}3-4 & \text { ft., } & \text { B\&B @ } & 3.50 \text { each } \\ 4-5 & \text { ft., } & \text { B\&B @ } & 5.00 \text { each } \\ 5-6 & \text { ft., } & \text { B\&B @ } & 8.00 \text { each } \\ 6-8 & \text { ft., } & \text { B\&B @ } & 10.00 \text { each } \\ 8-10 & \text { ft., B\&B @ } & 15.00 \text { each } \\ 10-12 & \text { ft., B\&B @ } & 25.00 \text { each }\end{array}$

Raphiolepis Umbellata. Japanese Hawthorn. Dwarf, slowgrowing evergreen. Beautiful foliage. Dainty clusters of pinkish-white flowers in spring. Large blue-black berries in winter. Unusual; distinctive; desirable.

15-18 in.@\$2.79 each

18-24 in.@3.79 each

2-3 ft.@4.95 each

\section{ROSES - Bush - Standard Varieties:}

Ami Quinard. Black red rose.

Bettsr Times. Very good red; bright color. Nice bud. Excellent for cutting.

Briarcliff. H.T. Good pink. Full flower. Holds form.

Christopher Stone. H.T. Dark red with velvet texture.

Condesa de Sastago. H.T. Beautiful, two-toned red and yellow.

Countess Vandal. H.T. Two-toned, soft pink. Very beautiful.

Crimson King. H.T. Red. Good bloomer. 
Etoile de Hollande. H.T. One of the best reds on the market. Good bloomer.

Eclipse. H.T. Most beautiful, long yellow brid. One of best yellows.

Editor McFarland. H.T. Clear pink; good form.

Floradora. Long-lasting florabunda. Geranium-red. Excellent cut flower.

Girona. Two-toned. Blend of pink, yellow and carmine. Vigorous.

Golden Ophelia. H.T. Old-fashioned. Very delicately shaded gold ivory.

Kaiserin Augusta Viktoria. H.T. Excellent white. Good form.

Luxembourg. H.T. Buff yellow. Good flower.

Paul Neyron. H.T. Old-fashioned pink. Very double flower. Long-lasting.

Peter Briarcliff. H.T. Nice pink.

Picture. H.T. Beautiful soft tones of pink. Good form and color.

Poinsettia. H.T. Very rugged red. Resists disease. Excellent choice.

President Hoover. H.T. Two-toned pink. Colors softer than Talisman.

Radiance. H.T. Rugged grower. Prolific pink. Easy to grow.

Red Radiance. H.T. Very hardy rose red.

Rouletti. Tom Thumb rose. Flower small double pink.

Talisman. H.T. Well known two-toned yellow and red. Beautiful bud. 
The Doctor. H.T. Very large pink. Striking and beautiful.

White Briarcliff. H.T. White form of Briarcliff.

\section{CLIMBING ROSES - NON-PATENTS}

Cl. Cecile Eirunner. Dainty, attractive florabunda of soft pink, commonly known as "Sweetheart".

Cl. Doubloons. Yellow.

Cl. Dr. Van Fleet. Dainty pink.

Cl. Etoile de Hollande. H.T. One of best, hardy reds. Prolific bloomer. Good grower.

Cl. K. A. Viktoria. H.T. White. Good quality.

Cl. Madam Gregoire Staechelin. Spanish Beauty. Lovely pink spring bloomer.

Cl. Marechal Niel. Old fashioned, fragrant, creamy yellow. A Southern aristocrat.

Cl. New Blaze. Vivid red.

Cl. Pauls Scarlet. Vivid red spring bloomer. Nice for fence or lamp post.

Cl. Pink Cherokee. Good single pink. Spring bloomer.

Cl. Radiance. H.T. Good clear pink.

Cl. Red Radiance. H.T. Sturdy and prolific.

Cl. Talismant. H.T. Two-toned red and yellow. Even better than bush type.

PRICES ABOVE ROSES:

2-Yr. @\$1.25 each; 3 or more@\$1.15 each 


\section{SPECIAL ROSE OFFER}

\section{FAMOUS NAME ROSES $\$ 5.25$}

Etoile de Hollande - one of the best reds Radiance - good pink - easy to grow. Red Radiance - deep rose, vigorous.

Luxembourg - buff yellow.

K. A. Viktoria - pure white, pointed petals.

\section{ROSES - PATENTED - BUSH}

Aztec. Rich, coppery red.

@ $\$ 3.00$ each; 3 or more @ \$2.75 each

Buccaneer. Intense yellow. Holds color. Free flowering. @ \$2.50 each; 3 or more@ $\$ 2.25$ each

Charlotte Armstrong. Deep rose-red. Excellent form.

(1) \$2.25 each; 3 or more@ $\$ 2.00$ each

Chrysler Imperial. A most beautiful red; well worth price. @ $\$ 2.50$ each; 3 or more @ $\$ 2.25$ each

First Love. Soft pink.

@ \$2.25 each; 3 or more@ $\$ 2.00$ each

Forty Niner. Two-toned red; very colorful.

@ \$2.25 each; 3 or more @ \$2.00 each

Fusilier. Bright, flaming red grandiflora.

@ \$2.50 each; 3 or more @ \$2.25 each

Golden Scepter. Good yellow

@ $\$ 1.85$ each; 3 or more @ $\$ 1.75$ each

Goldilocks. Very pretty, bright yellow. Good. Floribunda. @ $\$ 1.75$ each; 3 or more @ $\$ 1.50$ each

Happiness. Brilliant red, pointed buds. Long-lasting. Does well in hot weather.

@ \$2.00 each; 3 or more @ $\$ 1.90$ each

HeatWave.Red. @\$3.00 each; 3 or more@\$2.75 each

Helen Trauhel. Beautiful, two-toned pink.

@ $\$ 2.75$ each; 3 or more @ $\$ 2.50$ each

Ivory Fashion. Ivory white. Floribunda.

@ $\$ 3.00$ each; 3 or more@ $\$ 2.75$ each

Love Song. Soft pink.

@ $\$ 2.50$ each; 3 or more @ $\$ 2.25$ each 
Mirandy. Black-red. Very dark.

@ \$2.25 each; 3 or more@ $\$ 2.00$ each

Mission Bells. Glowing deep salmon, opening to shrimppink. Vigorous.

@ $\$ 2.00$ each; 3 or more@ $\$ 1.75$ each

Mojave. Deep copper-red.

@ $\$ 2.75$ each; 3 or more@ $\$ 2.50$ er.ch

Montezuma. Rich, copper color. Good bloomer.

(@) $\$ 2.75$ each; 3 or more @ $\$ 2.50$ each

Peace. Outstanding light yellow, rimmed carmine. Large.

@ $\$ 2.50$ each; 3 or more@\$2.00 each

Queen Elizabeth. Deep pink; good; strong grower. Grandiflora.

@ \$2.50 each; 3 or more@ $\$ 2.00$ each

Red Pinocchio. Very showy, dark red, thrifty, beautiful. Floribunda.

@ $\$ 1.75$ each; 3 or more @ $\$ 1.50$ each

Show Girl. Pink. @ \$2.25 each; 3 or more@\$2.00 each

Spartan. Orange red. Good color and blomer. Floribunda. @ $\$ 2.75$ each; 3 or more@ $\$ 2.50$ each

Starfire. New red. All America 1958!

@ $\$ 3.00$ each; 3 or more@ @2.75 each

Tifiany. Deep rose. Floribunda.

@ $\$ 2.00$ each; 3 or more @ $\$ 1.75$ each

White Knight. New white.

@ $\$ 3.00$ each; 3 or more @ $\$ 2.75$ each

\section{CLIMBING PATENTED ROSES}

Cl. Floradora. Geranium-red.

@ $\$ 2.50$ each; 3 or more @ $\$ 2.25$ each

Cl. Golden Showers. Yellow.

(@) $\$ 2.75$ each; 3 or more @ $\$ 2.50$ each

Cl. Peace. Pale yellow, rimmed carmine.

@ \$2.25 each; 3 or more @ \$2.00 each

Rosmarinus Officinalis. Rosemary. Dwarf evergreen. Foliage aromatic; flowers yellow. Old timey.

18-24 in., B\&B

@ $\$ 1.50$ each; 3 or more@ $\$ 1.40$ each 
Salix Babylonica. Weeping Willow. Neciduous; graceful drooping branches. Rapid grower.

2-3 ft. @\$1.00 each

3-4 ft.@1.50 each

Salix Discolor. Pussy Willow. Deciduous flowering shrub. Catkins very decorative in spring.

4-6 ft. @\$1.50 each; 3 or more @ \$1.40 each

Salix Japonica. Japanese Weeping Willow. More hardy than S. babylonica.

2-3 ft. @\$1.00 each

3-4 ft.@1.50 each

4-5 ft.@1.95 each

Salix Tortuosa. Corkscrew Willow. Unique. Everything about this plant is crooked - the trunk, the branches and the foliage. Most unusuai Has same graceful weeping characteristics a other Willows.

4-5 ft.@\$1.95 each

Salvia Greggi. Purple sage. Deciduous, low-growing shrub. Very showy, deep cerise flowers in summer. Drought-resistant.

$12-18$ in. @ $\$ 1.00$ each

18-24 in.@1.29 each

Salvia Leucantha. Perennial. Deep bluish-purple flower spikes, with few white lobes, in late summer. Medium height. Plant in April.

@.59 each

Santolina Incarna. Dwarf aromatic with light bluish-grean foliage. Thrives in hot, dry locations.

$21 / 4$ in. pots@.25 each

Santolina Sempervirens. Dark green form of above. Both varieties excellent low massing material.

4-inch pots@.50 each

Silaginella. Dwarf evergreen fern. Makes beautiful allyear ground covering in shady locations.

4-inch pots@.50 each;3 or more@.40 each

Snapdragons. Perennial. Very nice for spring flower and annual border. Good cut flower. We have colors of: Bronze, Pink, Rose, Yellow.

(@) $\$ 1.25 \mathrm{doz}$.

Spiraeas:

Anthony Waterer. Dwarf, semi-evergreen; bushy, compact growth. Deep pink, flat headed flowers throughout summer.

12-18 in.@\$1.00 each

18-24 in.@1.25 each 
Billiardi. Medium height, deciduous flowering shrub. Spikes of pink flowers in summer.

18-24 in.@\$.79 each

2-3 ft.@1.00 each

Prunifolia Plena. True Bridal Wreath. Deciduous; upright; rapid growing; good massing material. Button-like white blooms up and down stems in very early spring.

18-24 in.@\$.79 each

2-3 ft.@1.00 each

Reevesiana Lanceata. Deciduous, graceful grower of medium height. Double white flowers in early spring.

18-24 in. @\$.79 each; 3 or more @ \$.69 each 2-3 ft.@1.00 each;3 or more@.75 each 3-4 ft.@1.25 each;3 or more@1.00 each 4-5 ft.@1.49 each; 3 or more@1.29 each

Thunbergi. The fine, feathery, dwarf grower, which produces single white flowers in profusion in very early spring.

15-18 in.@\$1.00 each; 3 or more@\$.85 each 18-24 in.@1.25 each;3 or more@1.00each 24-30 in.@1.75 each; 3 or more@1.50 each 30-36 in.@1.95 each;3 or more@1.75 each

Vanhouttei. Deciduous; medium height; graceful, drooping habit. Very showy in spring with its white masses of flowers.

18-24 in.@\$.79 each

2-3 ft.@1.00 each

3-4 ft.@1.25 each

4-5 ft. @1.49 each

Stocks. Hardy, evergreen perennial. Medium height. Excellent bedding plant.

\section{Ball Apricot.}

Ball Supreme. Rich silvery rose.

\section{Ball White.}

Lilac. Improved; lavender.

\section{Purple Heart.}

Ruby. Red; improved.

\section{Ready in Spring $1959-\$ 1.25$ per doz.}

Strawberries. Klondyke-Blakemore. 
Syringa. French Lilac.

Abel Carriere. Double Purple.

Charles Joly. Double Dark Red.

Michel Buchner. Double Lavender.

Victor Lemoine. Double Pink.

2-3 ft. @\$2.50 each

Syringa. Persian Lilac.

Laciniata. Cutleaf; medium height; deciduous. Very fragrant lavender colored flower-spikes in summer.

18-24 in. @ \$1.00 each

2-3 ft. @ 1.50 each

Tamarix Gallica. Deciduous; medium height.

Feathery foliage. Lacy pink flowers in summer.

2-3 ft. @\$1.00 each

3-4 ft.@1.50 each

4-5 ft.@1.95 each

Teucrium. Semi-evergreen border plant. Low growing.

4-6 in.@\$.39 each; 3 or more @ \$.29 each 6-8 in.@.49 each; 3 or more@.39 each

Thea Sinensis. Tea Plant. Evergreen of medium height. Dark green foliage. White flowers in late summer. The actual tea plant of commerce. 15-18 in. @\$2.00 each; 3 or more@ @1.85 each 18-24 in. @2.59 each;3 or more@2.39 each 2-3 ft. @2.98 each;3 or more@2.75 each 3-4 ft.@3.48 each;3 or more@3.25 each

Thuja Aurea Conspicua. Tall conical conifer. Foliage yellowish-green; very conspicuous.

Good contrast.

2-3 ft.@\$2.98 each

3-4 ft.@3.59 each

4-5 ft.@4.25 each

Thuja Aurea Nana. One of our earliest plant introductions. Dwarf conifer whose new foliage is golden. Very popular.

15-18 in.@\$2.35 each; 3 or more@ @2.00 each 18-24 in.@2.98 each; 3 or more@2.75 each 24-30in.@3.49 each;3 or more@3.29 each 30-36 in.@3.79 each; 3 or more@3.59 each 
Thuja Bakeri. Medium height. Good conical form. Full base. Good color.

18-24 in.@\$1.00 each; 3 or more@\$.90 each 2-3 ft.@2.00 each; 3 or more@1.75 each

3-4 ft.@3.79 each; 3 or more@3.59 each

4-5 ft.@4.00 each;3 or more@3.75 each

5-6 ft.@4.75 each; 3 or more@4.50 each

Thuja Bonita. Globe-like conifer. Green; low-growing. 24-30 in.@\$3.49 each

Thuja Fruitlandi. Another of our own introduction. Globe type with dark green foliage.

1尺-24 in. @\$2.98 each; 3 or more@ @2.75 each 24-30 in. @3.49 each;3 or more@3.29 each 30-36 in.@3.79 each; 3 or more@3.59 each 3-4 ft.@4.49 each;3 or more@4.00 each

Trachelospermum Divaricata. Star Jasmine. Evergreen vine, having fragrant yellow star-shaped flowers.

Pots@\$1.50 each

Trachelospermum Jasminoides. Star Jasmine with white star-shaped flowers with same fragrance as yellow.

Pots@\$1.50 each

Trachelospermum Jasminoides Var. Same as above two varieties, except foliage is variegated. New! Tender!

(a) $\$ 1.50$ each

Trachycarpus Excelsa. Windmill Palm. Very hardy evergreen with fan-like foliage. Tall grower.

12-18 in. @\$2.49 each

18-24 in.@2.85 each

Tsuga Caroliniana. Carolina Hemlock. A very beautiful conifer, having small, graceful, dark green foliage. Does best in shady locations. Beautiful hedge material.

18-24 in.@\$2.50 each

Ulmus Pumila. Chinese Elm. Very rapid, deciduous shade tree. Vigorous.

$$
\begin{array}{rrr}
5-6 & \mathrm{ft} . @ \$ 2.59 & \text { each } \\
6-9 & \mathrm{ft} . @ 3.00 & \text { each } \\
8-10 \mathrm{ft} . @ & 4.75 \text { each } \\
10-12 \mathrm{ft} @ @ 6.25 & \text { each }
\end{array}
$$


Viburnum Burkwoodi. Semi-evergreen; medium height. Large clusters pinkish-white filowers in spring. Very fragrant. Good for massing.

$$
\begin{aligned}
& \text { 18-24 in.@\$2.25 each } \\
& \text { 2-3 ft. @3.25 each } \\
& \text { 3-4 ft.@3.59 each }
\end{aligned}
$$

Viburnum Odoratissimum. Large evergreen with bright green foliage. Excellent screening material. 8-12 in.@75c

Vinca. Periwinkle.

Major. Low, evergreen ground cover, having deep blue flowers. Stands full sun.

@10c each

Minor. Common Periwinkle. Ground cover. Shady location.

(@) 25c each

Variegata. Unusual green and white foliage to brighten up the deep shadows.

@25c each

Vitex Angus Castus. Chaste Tree. Deciduous, flowering tree having aromatic foliage and blue flower spikes.

18-24 in.@\$1.00 each

24-30 in.@1.59 each

Vitex Alba. White-flowering form of above.

18-24 in.@\$1.00 each

Vitex Negundo Incisa. Another blue flowering Chaste tree.

4-5 ft.@\$2.59 each

Zizyphus Jujuba. Raisin Tree. Deciduous. Beautiful compound foliage; edible fruit in late summer. Hardy.

2-3 ft.@\$1.85 each

3-4 ft.@2.00 each 




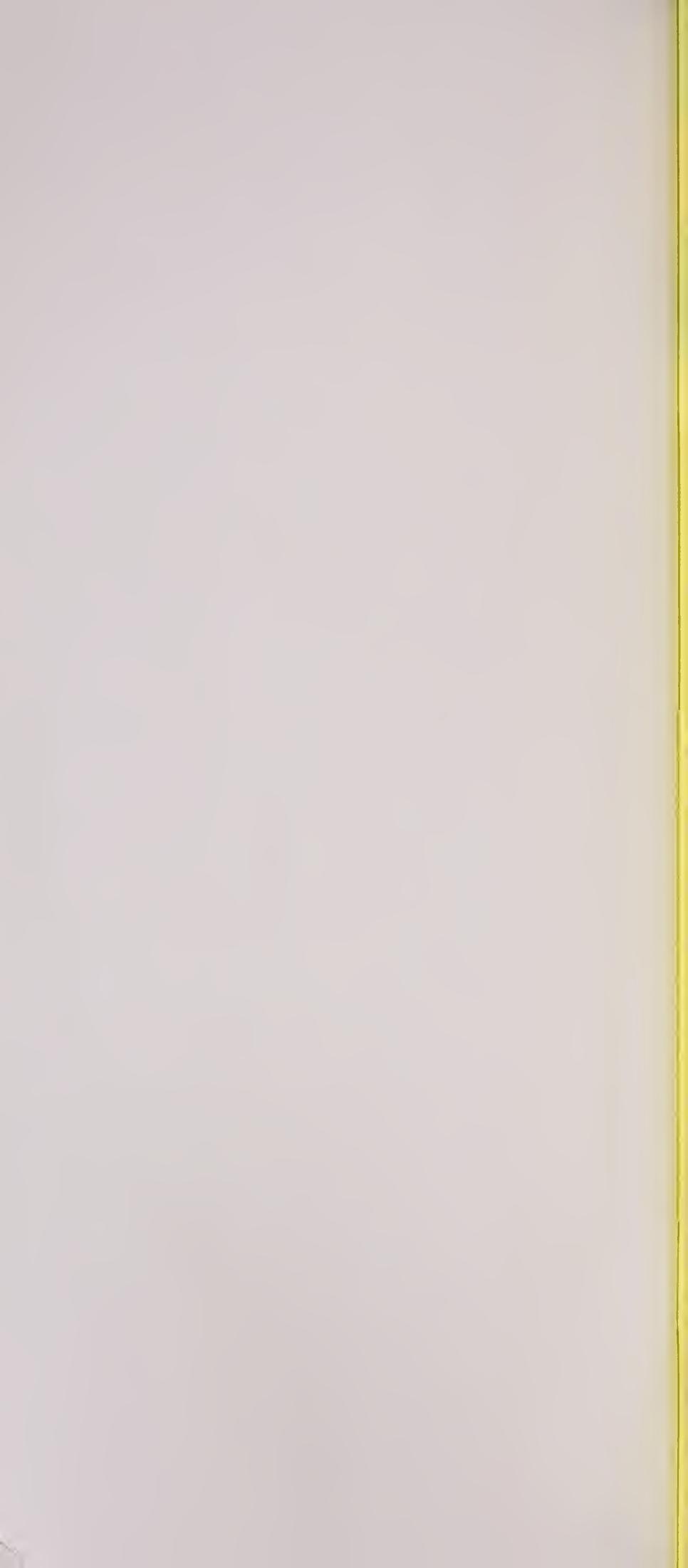




\section{PLEASE NOTE}

Due to problems and costs involved we hereby state:

All fruit trees above 4-5 feet

All flowering shrubs above 3-4 feet

All Broadleaved Evergreens above 18-24 inches

All Conifers above 18-24 inches

WILL NOT BE SHIPPED due to high transportation costs. However we do invite you to visit our nursery prepared to take your plants with you regardless of size and quantity. 
We hope you will like the layout of our new catalog. You will notice that all the items have been put in alphabetical order from $\mathrm{A}$ to $\mathrm{Z}$, thus enabling you to find them more easily.

The Nurseries are located at 2505 Washington Road on U. S. Highway \#28 west of Augusta. Phones Regent 3-8033 and 3-7927. We would like for you to visit us at our new modern Garden Center where you will find all your needs for a fine garden. WE ARE NOT OPEN FOR BUSINESS ON SUNDAY.

Our Nurseries are inspected annually by our State Plant Board and we guarantee our trees and plants to be in a healthy condition, true to name, up to grade and first class in every respect when leaving our hands. WE HAVE NO AGENTS. When requesting information or advice, please enclose stamped envelope.

WHEN TO PLANT. Our shipping season opens in the Fall after good rains and frost, and continue through April. We have many plants in containers that can be shipped at any time.

Any complaints or errors must be reported within sixty days. We cannot be responsible for plants dying from lack of water or other things beyond our control.

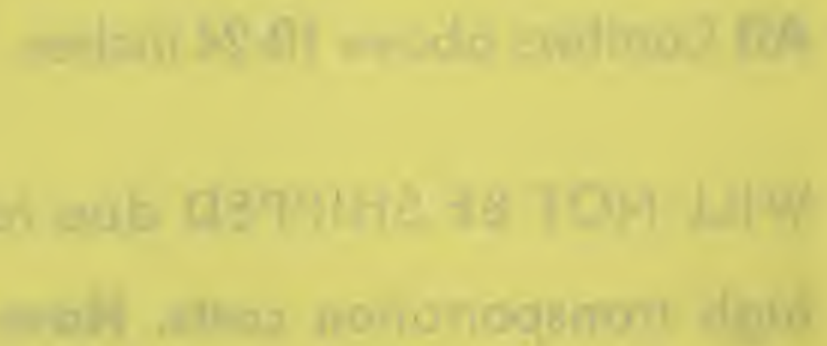

TERMS

Cash with order unless credit prearranged. If C.O.D. shipment is preferred, order must be accompanied with a deposit of 50 per cent. All prices F.O.B. Augusta. NO ORDER WILL BE ACCEPTED FOR LESS THAN $\$ 3.00$ DUE TO INCREASE IN SHIPPING COST. 


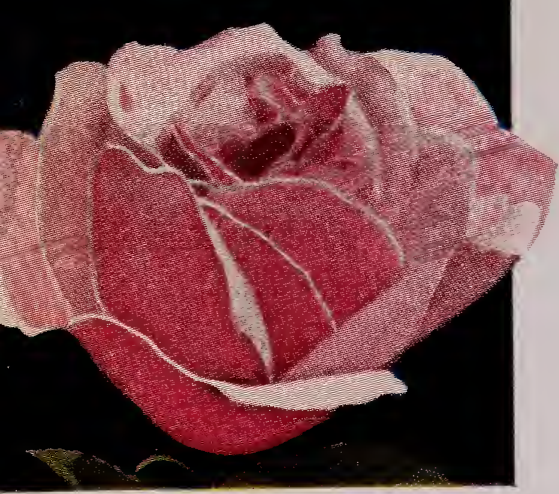

2-Year

\author{
Field
}

Grown

Rose

Bushes

PINK RADIANCE

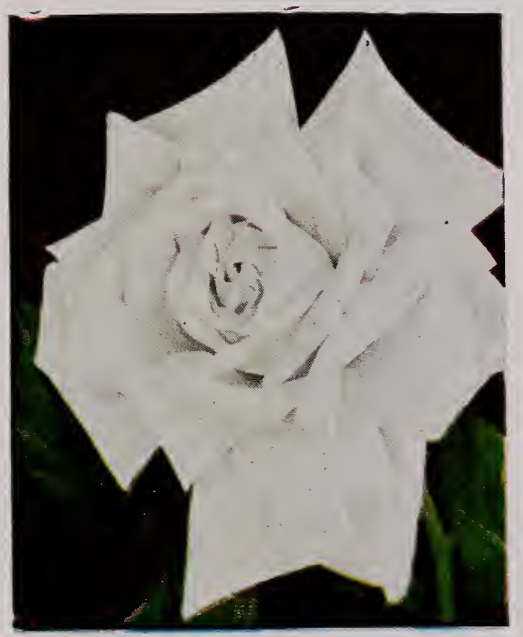

K. A. VIKTORIA

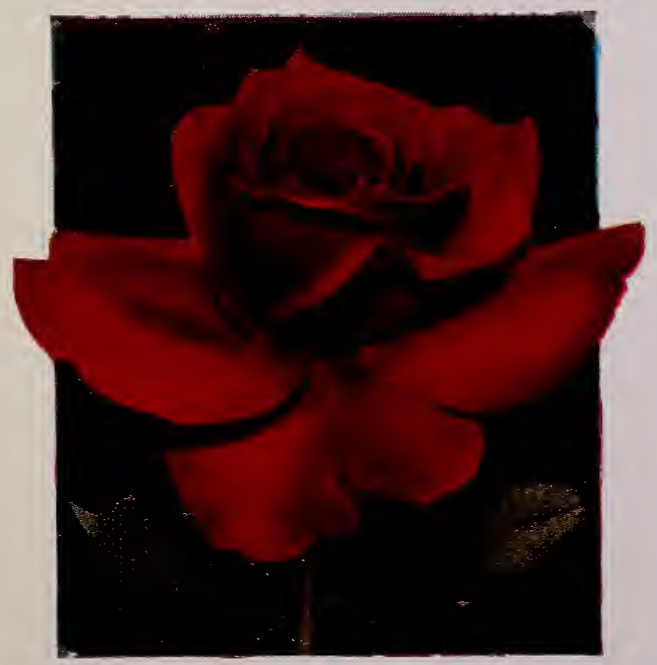

ETOILE DE HOLLANDE 


\section{Sacanqua}

Make excellent specimen, and screen planìs.

They are colorful, Evergreen, and Hardy.

Include a group in your planting plan this season.

See front cover for color illustration.

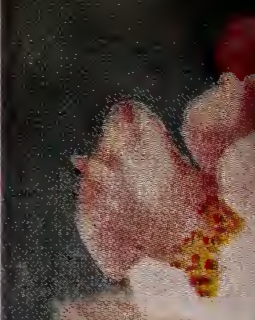

